\title{
ECONOMICS
}

\section{TRADE, WAGES AND SKILL ACCUMULATION IN THE EMERGING GIANTS}

by

Richard G. Harris

Simon Fraser University

and

Peter E. Robertson

Business School

The University of Western Australia

DISCUSSION PAPER 09.19 


\section{Introduction}

Three decades of falling trade barriers and rapid growth in emerging market economies has prompted an expansive literature on the effects of trade liberalization on wages. The Stolper-Samuelson theorem, which links changes in commodity prices to changes in factor returns, has occupied a central place in economic thinking about this issue. Standard applications of this model, however, ignore dynamic considerations that arise from the presence of training costs, adjustment costs, capital accumulation, and education investment.

As emphasized by Baldwin (1992), the dynamic effects of trade reform can be very large and may overshadow the traditional Stolper-Samuelson effects. These dynamic effects may also be particularly important for countries such as China and India - where rapid growth and rising wage inequality have been accompanied by large reductions in trade barriers and large increases in openness. ${ }^{1}$

The aim of this paper is to provide quantitative estimates of the dynamics effects of trade liberalization, particularly with respect to human capital accumulation and the transition paths of skilled and unskilled wages. We develop a model that links the neoclassical model of investment and growth, with standard competitive trade models and the BeckerSchultz-Mincer model of human capital. In separate applications we calibrate the model to China-USA and the rest-of-world (ROW), and India-USA-ROW scenarios. We solve the perfect foresight general equilibrium time path for these economies following trade liberalization in China and India, and report the impact, transition, and steady state effects for key variables.

We find that, in both China and India, trade liberalization triggers jumps in physical capital investment and education enrollments. The skill premium rises sharply on impact due to Mincerian on-the-job training costs and capital-skill complementarity. The path however is non-monotonic and falls in the long run. Despite rising wage inequality in the short run, trade liberalization is "pro-poor" in that it generates strong growth in unskilled labor wages and induces up-skilling of the labor force. The results thus give weight to the case for trade liberalization in emerging economies and also offer a new explanation for the widely observed positive relationship between trade liberalization and wage inequality in developing economies.

\footnotetext{
${ }^{1}$ China's share of world exports has increased from $2.5 \%$ in 1996 to $7.2 \%$ in 2006 . India's share of world exports were $0.6 \%$ in 1996 and $1.4 \%$ in 2006 . For the low and middle income countries as a whole the share of world exports increased from $19 \%$ to $28 \%$. The figures refer to the $\$$ US value of merchandize exports and are taken from the World Bank (2008).
} 


\section{Background}

\subsection{Trade-Wage Studies}

The debate over the consequences of economic integration and globalization on wages and incomes is extensive. ${ }^{2}$ Most studies have concluded that, despite the predictions of the Stolper-Samuelson theory, changes in trade flows have only had a minimal impact on wage inequality. Nevertheless, as Krugman (2008) explains, the earlier empirical literature may well understate the effects of trade on incomes in the last decade due to the rapid expansion of trade volumes, especially from China.

Though the debate originated over concerns of growing inequality in developed economies, a puzzling finding is that trade liberalization is also often associated with rising skill premiums in developing economies (see Winters et al 2004, Arbache et al 2004, and Goldberg and Pavcnik 2007). As these studies note, the result is contrary to what might be anticipated from a naive appeal to the Stolper-Sameulson theorem.

The alternative hypothesis is that rising wage inequality in both developed and developing countries is due to other factors, such as skill-biased technological change, or fragmentation and "off-shoring". ${ }^{3}$ An additional consideration is that the anticipated sign of Stolper-Sameulson effects in many developing countries may be reversed due to the pattern of protection. For example, according to Anderson (1994, 2003) and Goldberg and Pavcnik (2007), developing economies often have highly protected agricultural sectors. ${ }^{4}$

With respect to China and India specifically, Chaudhuri and Ravallion (2007) show that reforms have also been associated with rising in inequality. Moreover in both countries rising inequality appears to be associated with rising skill premiums, (see Dutta 2005

\footnotetext{
${ }^{2}$ Examples of the early literature include Lawrence and Slaughter (1993) and Berman, et al (1994). Katz and Autor (1999) and Slaughter (1999) also survey the early literature. Winter et al (2004), Arbache, Dickerson and Green (2004) and Goldberg and Pavcnik (2007) survey the more recent literature on developing countries. Richardson (1995) provides a useful discussion of trade-wage interactions in a growing economy. Krugman (2008) and Lawrence (2008) have revived the debate with respect to the impact of developing economies trade on the U.S. economy.

${ }^{3}$ Potentially skill-biased technological trade may be induced by trade liberalization. Models by Acemoglu (2003) and Aghion et al (2006) highlight this point. For an overview of the off-shoring arguments see Feenstra and Hanson (1999) and Baldwin and Robert-Nicoud (2006). As discussed below, several studies have also pointed to the potential importance of capital skill complementarity in understanding rising wage inequality.

${ }^{4}$ Other studies include Hertel et al (2003), who find that trade liberalization reduces the skill premium in 12 developing countries but increases it in Bangaldesh and Uganda, and Harrison, Rutherford and Tarr (2004) who find that trade liberalization reduces production labor wages in their CGE model of Turkey and attribute this to heavy protection in labor intensive sectors. See also Hertel et al (2004) and Winchester (2007).
} 
and Fleisher and Wang 2004). ${ }^{5}$

Nevertheless the literature on China and India also finds only a small role for trade in understanding the rising inequality. Chamarbagwala (2006) and Kijima (2006) argue that rising wage inequality in India resulted from mainly technological change not trade liberalization, and Mishra and Kumar (2005) and Aghion et al (2008) find that reforms led to a reduction in skill premiums in India. Similarly, with respect to China, Ianchovichina and Martin (2004) find that the WTO accession reforms would reduce skill premiums, and Anderson et al (2002) find that WTO accession reforms in China cause a small fall in the skill premium for non-farm labor but a widening gap between farm and non-farm unskilled labor. ${ }^{6}$ Thus the literature on China and India also suggests that trade liberalization is associated with rising, rather than falling, wage inequality.

\subsection{Models of Trade and Skill Accumulation}

As noted recently by Winters (2004), the question of whether trade liberalization induces human capital accumulation is an equally important but much less widely studied topic. Specifically there is little empirical evidence on the effects of trade liberalization on skill accumulation. Some notable exceptions are Arbache, Dickerson and Green (2004) who find that education levels rose in Brazil after trade liberalization, and Edmonds et al (2007), who find that trade liberalization in India reduced the costs of schooling. ${ }^{7}$

In contrast to the lack of evidence on human capital accumulation and trade, the theoretical issues are relatively well understood. A simple, but insightful, dynamic model by Findlay and Kierzkowski (1983) describes the basic long run relationship between trade and skilled labor accumulation. They consider a relatively standard Heckscher-Ohlin type model with two final goods produced by skilled and unskilled labor. They also include a third intermediate good, called "Education", which can be used to produce skilled labor.

Findlay and Kierzkowski (1983) then consider the long run effects of trade liberalization by characterizing how changes in commodity prices affect the steady-state equilibrium

\footnotetext{
${ }^{5}$ See also, for example, Chaudhuri and Ravillion (2007) for a discussion of the reforms and their impact on wage inequality in China and India, and Yusuf, Nabeshima, and Perkins (2007) for evidence on higher education enrollments.

${ }^{6}$ Trade liberalization was only part of the reform package in these countries however. The ongoing reforms in the education sector in India and China are documented respectively by Kapur and Mehta (2007) and Li et al (2008).

${ }^{7}$ Fleisher and Wang (2004) similarly note the need for increasing skilled wage to promote education enrollments in China, and Wood and Calandrino (2001) also note the potential for trade to raise skill levels in India and China.
} 
factor prices and the quantity of skilled labor. They find that trade liberalization induces skill accumulation in a skilled labor abundant country, skill de-accumulation in an unskilled labor abundant country, and has no long run effect on the skill premium. The model thus shows how trade can influence the cost of producing skilled labor and the skill composition of the labor force.

Other models to examine these interactions include Das (2001, 2006), Deardorf (2000), Long, Riezman and Soubeyran (2007), Flavey (et al) 2007 and Bond, Trask and Wang (2003). In particular Das (2001) draws attention to the potential importance of supervision and management tasks of skilled workers. Das (2006), Falvey et al (2007), Bond, Trask, and Wang (2003) among other develop models where the dynamics of human capital formation, or skill acquisition, play important roles, thus moving away from long run steady state analyses, or fixed endowment models. ${ }^{8}$

Nevertheless, by comparison to the large literature on trade and wage inequality, little attention has been paid to how trade reforms might affect human capital accumulation and growth, or how allowing for factor accumulation might affect the behavior of the skill premium over time. Of particular interest are the short run, or impact effects in dynamic models, which reflect jumps in asset prices and investment demands, once the trade reform is announced. This paper represents the first attempt in the literature to quantify these dynamic effects. Specifically it examines the transitional dynamics in a model of trade, growth and human capital accumulation, which also includes on-the-job training costs for skilled labor and forward looking behavior by agents.

Looking at these dynamic impacts, however, poses some significant analytical challenges. First, we must derive solutions for the transition path rather than just focusing on the steady state. The instability of saddle point equilibria in these models means that solving the transition path requires iterative methods that are computationally expensive (Timo et al 2008, Dixon et al 1992).

Second, whereas calibrated growth models are typically highly aggregated, this parsimony is very restrictive when considering international trade. Aggregation causes averaging

\footnotetext{
${ }^{8}$ Deardorf (2000) considers a model with endogenous skill formation, where time is the only input into human capital investment and agents are heterogeneous. His focus is on skill premium effects of various policies rather than skill accumulation. Ranjan (2001) extend the Findlay and Kierzkowski (1983) model to consider the interaction between trade liberalization and borrowing constraints, and the implications for human capital investment, and Das (2006) further extends this model to look at the dynamics of income distribution. Long, Riezman and Soubeyran (2007) also extend the Findlay and Kierzkowski (1983) model to include firm-specific skills. Falvey et al (2007) examine the effects of adjustment costs on different generations and Bond, Trask, and Wang (2003) observe the possibility of multiple equilibria in a model with trade and endogenous growth. For a discussion of policy issues also see Abrego and Edwards (2002).
} 
across commodity and factor prices and, hence, limits the extent to which tariff changes can affect commodity and factor prices. Therefore, in what follows, we develop and solve a disaggregated dynamic model that can more readily accommodate these commodity and factor price linkages.

\section{A Model of Growth and Trade}

Growth models are typically limited to one or two sectors and a similar number of factors. As noted this aggregate approach is not well suited to analyzing growth and trade linkages since the potentially large changes in prices, implied by trade liberalization, are averaged into smaller changes across the small commodity space.

In order to minimize the problem of averaging commodity price and rental rate changes we consider a growth model which, in terms of its dimensions, is closer to traditional computable applied trade models than traditional growth models. In this section we briefly describe the general features of the model and give a detailed description of the dynamics below. A more detailed description of the model is given in Appendix B.

We consider a disaggregated version of the standard neoclassical open economy model of investment with installation costs. Investment decisions of agents depend on current and future asset prices, factor returns and current stocks. These investment decisions include human capital investments through tertiary education decisions.

The model is divided into three regions, $\bar{R}=\{1,2,3\}$, where region 1 is the USA, 2 is China or India depending on the application, and region 3 corresponds to the Rest of World (ROW). ROW purchases imports from the other two markets at exogenous ROW prices. The ROW region also exports to the other two regions at prices which are endogenous to that region. The allocation of ROW's supply to each non-ROW region is thus endogenous. The two non-ROW regions, which we label the subset $R=\{1,2\}$, face exogenous ROW export prices. Within each non-ROW region, however, prices depend on demand and total supply from each other market. Thus an expansion of exports in China, for example, will have an impact on China's terms-of-trade due to its effect on supply in U.S.A. markets.

In the non-ROW regions, goods are produced using primary factors and intermediate inputs. There are eleven sectors, $I=\{1, \ldots, 11\}$, of which the first six are traded goods, $I_{T}=\{1, \ldots, 6\}$. Firms producing traded goods are joint producers of three destination specific goods - one for each market. They choose the relative supply to each market 
by maximizing a constant elasticity of transformation revenue function subject to the producer prices in each market. Thus, unlike many applied trade models, imports and domestically produced goods are perfect substitutes, and firms face infinitely elastic ROW demand for their exports. This means that the law of one price holds in each market. In addition factors are also perfectly mobile and together, these structural assumptions mean that the model is very similar to standard trade models, such as the HeckscherOhlin model. ${ }^{9}$

Nevertheless exports to the non-ROW markets face downward sloping demands. Hence factor prices are not completely determined by world commodity prices as in the small open economy model. In particular factor prices can change in response to factor supplies, and hence the pure Rybczynski result and Stolper-Samuelson results need not hold.

In order to focus on Stolper-Samuelson type linkages between traded goods prices and factor prices we also need disaggregation of factor inputs. Thus we include seven factors of production, $\bar{K}=\{1, \ldots, 7\}$ where the subset $K=\{1, \ldots, 3\}$ consists of the physical capital, Machinery and Equipment, Structures and Residential Capital. The remaining factors are Skilled and Unskilled labor and the subset $N=\{6,7\}$ refer to Land and Resources. Firms choose these factor inputs, and intermediate inputs, to minimize unit costs, taking prices as given. Constant returns to scale production functions ensures that the unit cost function is separable from output levels. Free entry and exit ensures zero profits in equilibrium. Endowments in the ROW are described by a single variable which grows exogenously through time, and ROW total commodity supply, to its domestic market and each other market, likewise grows exogenously as a fixed proportion of the endowment.

Final commodity demands by private households and governments arise from constant elasticity of substitution (CES) unit expenditure functions and CES investment expenditure functions. The demand levels at a point in time depend on the optimal paths from the household's education, consumption and investment inter-temporal maximization problems, which are discussed below.

A "static equilibrium" requires zero profits, commodity market clearing and factor market clearing in each market. Trade does not need to be balanced in a static equilibrium, but there is a steady-state debt target which must be satisfied in a dynamic equilibrium. A dynamic equilibrium is a sequence of static equilibria that satisfy the perfect foresight investment plans, the education plan described below, a consumption plan, and

\footnotetext{
${ }^{9}$ The more standard approach in applied trade models is to employ the "Armington" assumption that consumers have strictly convex preferences over imports and domestic goods so that these are imperfect substitutes. See Abrego and Whalley (2000, 2003) for discussions of the Armington assumption.
} 
approaches a balanced growth path where all prices are constant and all per capita effective factor stocks are growing at a common constant rate. Formal definitions of these static and dynamic equilibrium conditions are given in Appendix B.

\subsection{Human Capital Accumulation}

Human capital accumulation is derived from a standard "Becker-Schultz-Mincer" type model of education decisions. For simplicity of notation we focus on a single country and omit the regional index. Let the working population, or labor force, at time $t$ be denoted $P_{t}$. The net increase in the labor force is,

$$
P_{t+1}=(1+b-d) P_{t}
$$

where $b$ is the birth rate, $d$ is the retirement rate. At a point in time the labor force is defined in terms of skilled labor, $L S_{t}$, unskilled labor, $L U_{t}$, and stock of students, $H_{t}$.

$$
P_{t}=L S_{t}+L U_{t}+H_{t}
$$

The stock of skilled labor depends on past schooling decisions by unskilled workers. There is an endogenous flow of students graduating each year and entering the skilled labor force. Denoting this flow of skilled entrants as $E_{t}$, we have, as an approximation, $E_{t}=H_{t} / \zeta$ where $\zeta$ is number of years in tertiary education. ${ }^{10}$ The updating equation for skilled labor is then

$$
L S_{t+1}=L S_{t}+H_{t} / \zeta-d L S_{t}
$$

For future reference note that an implication of (3) is that, on a steady state, where the ratio of skilled labor to total labor, $L S_{t} / P_{t}$, is constant, the stock of students is a constant proportion of the stock of skilled labor, that is, $H=b \zeta L S .^{11}$

Following Becker (1962) and Schultz (1960), the costs of acquiring education include the opportunity cost of forgone wages and direct education costs. Furthermore, as first emphasized by Mincer (1962), on-the-job training costs are also a significant cost of

\footnotetext{
${ }^{10}$ This approximation ignores lags that occur between the build up of enrolments and the flow of graduates.

${ }^{11}$ Dividing (1) by $L S_{t}$, noting that $L S_{t+1} / L S_{t_{t}}=1+b-d$, and re-arranging gives $H / L S=b \zeta$ as claimed. This holds irrespective of the nature of the dynamics, i.e. whether they are forward-looking or recursive. Essentially, any model of skill accumulation that permits a steady state must exhibit a similar relationship between skilled labor inflows and education, as long as both types of skilled labor produce the same factor services.
} 
acquiring human capital. ${ }^{12}$ This training role of skilled labor has been largely ignored in the trade-wage literature, the sole exception being Das (2001). ${ }^{13}$

The optimal pattern of investment in schooling is therefore chosen by a representative household who maximizes the present value of skilled and unskilled labor incomes subject to on-the-job training costs. Given a world rate of interest, $\rho$, the present value of the net stream of skilled and unskilled wages earned by a household is given by

$$
\sum_{t=0}^{\infty} \frac{1}{1+\rho^{t}}\left[u_{L S, t}\left(L S_{t}-J\left(H_{t}, L S_{t}\right)\right)+u_{L U, t} L U_{t}-q_{e, t} A_{e, t} H_{t}\right]
$$

where $u_{L S, t}$ is the after tax skilled wage, $u_{L U, t}$ is the after tax unskilled wage, $q_{e, t}$ is the consumer price of education. The product $A_{e, t} H_{t}$ is the output of the education services which is proportional to the stock of students. Hence $q_{e, t} A_{e, t} H_{t}$ is the direct cost of schooling to the household. ${ }^{14}$ The returns to skilled labor are net of on-the-job training cost, $J\left(H_{t}, L S_{t}\right)$. Specifically, we assume that the on-the-job training function takes the form,

$$
J\left(H_{t}, L S_{t}\right)=\frac{\beta_{e}\left(H_{t}-b \zeta L S_{t}\right)^{2}}{2 L S_{t}} .
$$

Since $H=b \zeta L S$ on a steady state, (5) says that it is costly to raise, or lower, the flow of new entrants into the labor force from the steady state level, $b \zeta L S$. These costs reflect both the lower productivity of new workers and the use of skilled labor time used in formal training, such as internships, training programmes and informal learning in the workplace (see Bishop 1991, Mincer 1994). The training costs in (5) serve to generate a well defined interior "Tobin-Q" demand for education function. They also imply a reduction in the effective supply of skilled labor available for production when education flows deviate from the steady state path.

The household's objective is then to maximize (4) subject to (1), (2), (3) and (5). The

\footnotetext{
${ }^{12}$ Conventional estimates of on-the-job training costs suggest that they are large. Mincer (1994) finds that these costs are large and account for $75 \%$ of observed wage growth. Similarly, Bishop (1991) finds that, for managers and professional occupations, hiring and training of new workers causes up to a $69 \%$ fall in productivity over the first 3 months, relative to increasing the hours of workers who have 2 years experience. See also Barron, Berger, and Black (1999) for some related evidence.

${ }^{13}$ The importance of on-the-job training in particular has been widely appreciated in the literature on computer use and the "productivity paradox" Helpman and Rangel (1999).

${ }^{14}$ The efficiency parameter $A_{e, t}$ grows at the steady state rate $1+\gamma$. Without this exogenous growth, education output would become infinitesimally small relative to the supply of skilled labor. This ensures that, on a steady state, the education sector produces output of the same "quality" as the augmented skill level of the labor force.
} 
first order conditions are

$$
\begin{gathered}
-u_{L S, t} J_{1}\left(H_{t}, L S_{t}\right) \zeta-u_{L U, t} \zeta-q_{e, t} A_{e, t} \zeta+\Pi_{e, t}=0, \\
-\Pi_{e, t}+\frac{1}{1+\rho}\left(u_{L S, t+1}\left(1-J_{2}\left(H_{t+1}, L S_{t+1}\right)\right)-u_{L U, t+1_{t}}+(1-d) \Pi_{e, t+1}\right)=0 .
\end{gathered}
$$

Equation (6) says that the shadow price of a unit of skilled labor is equal to the sum of the variable cost of education per unit, the opportunity cost and the marginal adjustment cost. From (5) the marginal adjustment cost function is $J_{1}\left(H_{t}, L S_{t}\right)=\beta_{e}(H / L S-b \zeta)$. Substitution into (6) gives

$$
\frac{H_{t}}{L S_{t}}=\frac{\prod_{e, t} / \zeta-u_{L U, t}-q_{e, t} A_{e, t}}{\beta_{e} u_{L S, t}}+b \zeta
$$

which can be interpreted as a demand for schooling function. It shows that variations in demand schooling will depend on: the asset value of skilled labor relative to the current wage rate $\Pi_{t} / u_{s, t}$; the inverse skill premium, $u_{L U, t} / u_{L S, t}$, and; the direct costs of education, $q_{e, t}$.

Equation (7) is the inter-temporal arbitrage condition, which equates the asset price of a unit of skilled labor to the discounted benefit one period into the future. These net benefits are: the net wage premium $u_{L S, t+1_{t}}-u_{L U, t+1}$; the effect of the unit of skilled labor on adjustment costs, $u_{L S, t+1} J_{2}(\cdot)$, and; the next period sale value of the asset, $(1-d) \Pi_{e, t+1}$.

\subsection{Steady State Growth Path}

We define a steady state growth path (or balanced growth path) as a growth path where all stocks are growing at the growth rate of the effective labor force, $(1+n)(1+\gamma)$, where $n$ is the growth rate of labor and $\gamma$ is the growth rate of effective labor units. Along this path, the wage rates, $u_{L S, t} u_{L U, t}$, and shadow price $\Pi_{e, t}$, must be growing at the growth rate of productivity, $1+\gamma$. In view of this it is useful to redefine these wage rates and shadow prices in terms of efficiency units that will be stationary. Consider the efficiency or productivity variables $A_{L S, t}$ and $A_{L U, t}$ which grow exogenously at rate $1+\gamma$. Hence $A_{L S, t} L S_{t}$ and $A_{L U, t} L U_{t}$ are effective units of skilled and unskilled labor. We define an efficiency adjusted shadow price of skilled labor, and the wage rates per efficiency unit as: $\hat{\Pi}_{e} \equiv \Pi_{e, t} / A_{L S, t} ; \hat{u}_{L U, t}=u_{L U, t} / A_{L U, t}$, and; $\hat{u}_{L S, t}=u_{L S, t} / A_{L S, t}$. On a steady state we have $\hat{\Pi}_{e, t}=\hat{\Pi}_{e, t+1}, \hat{u}_{L S, t}=\hat{u}_{L S, t+1}, \hat{u}_{L U, t}=\hat{u}_{L U, t+1}$ and $J_{2}(\cdot)=0$. In 
the benchmark we choose units so that the ratio of efficiency units of unskilled to skilled labor is $A_{L U} / A_{L S} \equiv 1$. Given these assumptions, (7) and (6) can be rearranged to give

$$
\hat{u}_{L S}-\hat{u}_{L U}=\left(q_{e}+\hat{u}_{L U}\right)(\zeta / \Delta)
$$

where $\Delta \equiv(1+g) /((1+\rho)-(1-d)(1+g))$. Equation (9) is thus a steady-state relationship between the returns to skilled and unskilled labor, and the consumer price of education. Thus the steady state value of the skill premium, $\hat{u}_{L S} / \hat{u}_{L U}$ depends on the number of years of schooling it takes to complete tertiary education, $z$, and the consumer price of education (including subsidies) relative to the after tax unskilled wage, $q_{e} / u_{L U}$. In a steady-state equilibrium, the stock of skilled labor must adjust so that (9) is satisfied.

\subsection{Education Supply}

Education services are produced by a non-traded competitive industry. Production requires intermediate and primary factor inputs. Dual to the value added function of primary inputs is a nested constant elasticity of substitution (CES) unit cost function, $c_{e}(\hat{w})$, where $\hat{w}$ is the vector of factor prices per effective unit of each factor. Zero profits in the education sector imply

$$
p_{e, t}=\left(c_{e, t}\left(\hat{w}_{t}\right)+\sum_{j} a_{j, e, t} p_{j, t}\right)
$$

where $p_{e, t}$ is the producer price of education, $a_{j, e, t}$ is the input coefficient for intermediate good $j$ demanded by the education sector, and the $p_{j, t}$ is the price for intermediate input $j$. The consumer price of education is

$$
q_{e, t}=\left(1-s_{e, t}\right) p_{e, t}
$$

where $s_{e, t}$ is an education subsidy. Finally, educational output is assumed to be proportional to the number of students enrolled in a given year. Hence

$$
y_{e, t}=A_{e, t} H_{t}
$$

\subsection{Investment}

The three types of physical capital in the set $K$ are produced using intermediate goods. The demands for these investment goods are determined by the standard neoclassical 
model of investment with quadratic installation costs. Thus, firms choose investment plans for each type of capital to maximize the present value of each net capital stock. Given a world interest rate the investment, education, and household consumption plans are separable.

The optimal investment plan is the solution to choosing a sequence of gross investment spending to maximize the net present value of the asset, given a world rate of return $\rho$, and a quadratic installation cost function, $C_{k}\left(Q_{k, t+1}, V_{k, t+1}\right)$ where $Q_{k, t}$ is real investment in capital type $k$, and $V_{k, t}$ is the stock of capital $k$.

The Fisher problem yields the following first order conditions for capital type $k \in K$,

$$
\begin{gathered}
\frac{Q_{k, t}}{V_{k, t}}=\frac{\Pi_{k, t}-e_{k, t}}{\beta_{k, t} u_{k, t}}+\gamma+\delta_{k} \\
\prod_{k, t}=\frac{1}{1+\rho}\left[\left(u_{k, t+1}-u_{k, t+1} C_{k, 2}\left(Q_{k, t+1}, V_{k, t+1}\right)+\left(1-\delta_{k}\right) \Pi_{k, t+1}\right]\right.
\end{gathered}
$$

where: $\Pi_{k, t}$ is the shadow price of a unit of capital of type $k ; e_{k}$ is a constant elasticity of substitution (CES) unit expenditure function, investment price index, for investment type $k \in K ; u_{k}$ is after factor tax rental rates, $\beta_{k}$ is a parameter of the installation cost function, $\gamma$ is the steady state growth rate of the economy, $\delta_{k}$ is the depreciation rate for skilled labor, and; $C_{k, 2}\left(Q_{k, t+1}, V_{k, t+1}\right)$ refers to the marginal adjustment costs with respect to a change in the capital stock $V_{k, t+1}$.

The solution to this problem is a stream of asset prices and rental rates, that satisfy (13) and (14) at each point of time. Likewise, the rental rates, commodity prices, which are arguments of the expenditure functions $e_{k, t}$, and gross outputs, which underlie the real investment quantities, $Q_{k, t}$, must satisfy a static equilibrium at each point in time.

On a steady state (13) and (14) reduce to the familiar conditions that the investment is proportional to the capital stock, and the rental rate is proportional to the world interest rate.

$$
\begin{gathered}
Q_{k} / V_{k}=\gamma+\delta_{k} \\
u_{k} / e_{k}=\rho+\delta_{k}
\end{gathered}
$$

Finally the household consumption plan is obtained from minimizing a loss function of deviations of consumption spending and debts from the steady state consumption level and a debt target, which is assumed to be zero. The value of the long run consumption spending ratio to GDP is the unique value that satisfies the debt target in the steady 
state. Government expenditure is determined by a policy rule that spending is a constant fraction of GDP. The government balances its budget in every period using lump sum taxes or subsidies to return deficits or surpluses from consumption taxes and tariff revenues. $^{15}$

\subsection{Technology}

Each firms' technology is represented by a unit cost function of primary inputs and intermediate inputs, where the latter are used in fixed proportions. A key idea in the trade-wage literature is that capital-skill complementarity (KSC) in technology may explain part or all of the rising skill premiums in developing economies where there has been technology growth or capital market reforms. ${ }^{16}$ In order to allow for KSC we assume that these unit cost functions for primary inputs are represented by nested CES functions. Skilled labor and capital enter in a lower nest aggregate, and labor and other fixed factors enter in the upper level. The unit cost function for sector $i$ is,

$$
c_{i, t}(\hat{w})=\left(\delta_{\theta} \theta_{i, t}^{\sigma}+\delta_{L U} \hat{w}_{L U, t}^{\sigma}+\sum_{k \in N} \delta_{k} \hat{w}_{k, t}^{\sigma}\right)^{\frac{1}{\sigma}}
$$

where,

$$
\theta_{i, t}=\left(\sum_{k \in K} \delta_{k} w_{k, t}^{\nu}+\delta_{L S} \hat{w}_{L S, t}^{\nu}\right)^{\frac{1}{\nu}}
$$

Factor demands are derived from these cost functions using Shephard's lemma. Given this nested CES functional form the direct elasticity of substitution across the reproducible capital factors is equal to $1-\nu$. Likewise the degree of substitution across unskilled labor and the exogenously supplied factors, land and resources, is $1-\sigma$. KSC is satisfied if $1-\sigma>1-\nu$, or equivalently $\sigma<\nu$.

\subsection{Model Calibration Overview}

The benchmark equilibrium is calibrated to steady state growth path where all variables are growing proportionally, prices and factor returns and the debt to GDP ratio are constant, and there is balanced trade. The benchmark tariff rates for China and India are given in Table 1. China's average import-weighted tariff is $14 \%$ and India's is $24 \%$. The benchmark trade shares for China and India are also summarized in Table 2. They

\footnotetext{
${ }^{15}$ Further details are given in Appendix B.

${ }^{16}$ Examples of this literature include Stokey (1996), Tyers and Yang (2000), Krusell et al (2000), Behrman et al (2000), Acemoglu (2003), Aghion et al (2006) and Winchester and Greenaway (2007).
} 
show China's and India's large surplus of Low-Tech Manufacture and also the relatively large Durables export share for China, and Services export share for India. ${ }^{17}$ Calibration also requires choosing the parameters of: the unit expenditure functions for each of the spending aggregates; the unit revenue functions that determine the allocation of outputs across international markets; and the unit cost functions that describe factor input choices by firms. The parameter values are given in Table 3. The parameters of the nested CES production functions are taken from Krusell et al (2000).

We equate the stock of skilled labor to the population as equivalent to Barro and Lee's (2001) figures for the fraction of the labor force aged 15 and over who have completed tertiary education. This value is $2.2 \%$ of the labor force in India in 2000 and $2.1 \%$ in China. Education output flows are equal to total tertiary education spending which is obtained from UNESCO (2008) data, for India and the OECD (2002) data for China. In both China and India tertiary education spending represents just under one percent of GDP. Finally we choose the parameter of the on-the-job training costs function, $\beta_{e}$, so that the half-life of skilled labor accumulation is 10 years. The data and key variables from this calibration process are summarized in Table 4.

[Insert Tables 1-4 about here]

\section{Results}

The key issue of interest is the dynamic effects of trade liberalization. In particular we wish to compare the short run and long run effect of trade liberalization on the skill premium. We therefore consider the effect of unanticipated unilateral tariff elimination in China and India, and compare the solution with the benchmark.

To obtain the short rum, or impact, results we need to solve the entire transition path for the economy. The model is solved by integrating the path with an initial guess solution for the eight shadow prices, $\Pi_{k, t}^{r}$ and $\Pi_{e, t}^{r}, k \in K, r \in R$, from (14) and (7). The guess solution is updated using an algorithm by Wilcoxin (1988). For each iteration the model is solved for a finite period that is long enough for the solution to approximate the infinite horizon steady state. Consistent with the definition of an equilibrium, a solution is obtained when the expectations of future asset prices for each type of capital are equal to actual asset prices.

\footnotetext{
${ }^{17}$ The main data sources are Dimaranan (2006) and Penn World Tables, and Brown and Stern (2001).
} 


\subsection{Impact and Steady State Results for China}

Table 5 presents summary results showing the effect of trade liberalization on impact, and in the steady state. Additional results, including the effects during the transition, are given in the Tables A1 and A2 in Appendix A. The tariff elimination results for China are are reported in columns 1 and 2, and the results for the same experiment for India are reported in columns 3 and 4 .

Considering the China case first, it can be seen that trade liberalization generates strong growth in both unskilled wages and skilled wages of $4.7 \%$ and $3.7 \%$. Thus the long run effects are positive for all wage earners and trade has a dampening effect on wage inequality, with the skill premium falling by $1 \%$. Second, it can be seen that the physical capital, Machinery and Equipment and Structures increase by approximately $13 \%$ and $10 \%$ respectively, and there is a $7.9 \%$ increase in skilled labor. Thus, in the long run, trade liberalization generates significant capital and skill deepening.

How do these steady state effects compare with the effect on impact? As noted above the short run dynamic response can be obtained only by solving the entire perfect foresight transition path. ${ }^{18}$ Given the high levels of capital and skill deepening in the steady state results, it is evident that over the transition, there must be an increase in the rates of investment and education. The impact effects thus reflect not only the fixed factor supplies, but also the effect of expectations on investment demands, on-the-job training costs and capital installation costs. These short run effects are of particular interest since they are not captured in standard static models or "recursive" dynamic models that do not have forward-looking expectations.

As shown in Column 1 of Table 5 the impact results for China contrast dramatically with the steady state results. Importantly, the impact of trade liberalization on the skill premium, $w_{L S} / w_{L U}$, is shown on impact to increase by $1.7 \%$ compared to the decrease of $-1 \%$ in the steady state. Thus the effects of trade liberalization on the skill premium are non-monotonic and change sign. ${ }^{19}$ The short run rise in the skill premium also causes education enrollments to expand by $3.4 \%$ on impact. As discussed, this increase in the skill premium may reflect standard Stolper-Samuelson effects as well as short run dynamic effects associated with education demands and adjustment costs. We shall return to exploring this issue in Section 5.4 and Section 6 .

\footnotetext{
${ }^{18} \mathrm{An}$ initial value of consumption is also required, though this is not independent of the initial foreign asset stock. See Appendix B for details.

${ }^{19}$ As shown in Appendix A the skill premium increases by more than $2 \%$ over the transition before falling.
} 


\subsection{Impact and Steady State Results for India}

Summary results of the unilateral trade liberalization experiment for India are also given in Table $5 .{ }^{20}$ Given the larger initial tariffs it is not surprising that trade liberalization generates larger impacts than was the case for China. For India, real incomes increase by $19 \%$ and the stock of skilled labor rises $20 \%$ above the base case. Similarly, there is substantial capital deepening in Machinery and Equipment (35.7\%) and Structures $(27.9 \%)$.

The difference between the impact and steady state results are also dramatic. The skill premium jumps by $8.1 \%$ on impact, but falls over the transition. There is a $0.7 \%$ decrease in the steady state skill premium relative to the base. Thus in both India and China wage inequality falls in the long run but rises sharply in the short run. The short run result is the same as the counter-intuitive evidence discussed in the literature on trade wage effects in developing countries. In sections 6 and 7 below, we explore the reasons for this rise in wage inequality on impact.

The results also show that, despite rising wage inequality, tariff elimination in both countries generates large increases in unskilled wages. Thus, despite the short run increase in wage inequality, trade induced growth in these simulations is "pro-poor" both in the short run and the long run. ${ }^{21}$

\subsection{Long Run Rybczynski Effects}

The long run results indicate that quite large changes in factor "endowments" occur following trade liberalization. How can these changes in factor supply be accommodated by changes in factor demands? For example, is the increase in skilled labor accommodated by an expansion of skilled labor intensive sectors, with given factor returns, or is it due to substitution toward skilled labor by the fall in the skill premium in the long run? To this end we use a "Rybczynski decomposition" to assign these changes in factor demands to changes in the industry structure of output at given factor returns (output effect), and changes in the demand per unit of output due to changes in the relative factor returns (unit demand effect).

\footnotetext{
${ }^{20}$ Again more detailed results are given in Appendix A.

${ }^{21}$ For a discussion of "pro-poor" growth issues and definitions see Dollar and Kray (2002) and Ravillion and Chen (2003).
} 
Thus demand in sector $i$, for factor $j$ is

$$
\frac{\partial c_{i}(\hat{\mathbf{w}})}{\partial \hat{w}_{j}} g_{i}
$$

where, by Shephard's lemma, $l_{i, k}=\partial c_{i}(\hat{\mathbf{w}}) / \partial \hat{w}_{j}$ is the unit demand for factor $j$ in sector $i$, and $g_{i, k}$ is the gross output index for sector $i$. Tables 6 and 7 report the decomposition. Specifically they report: the "unit demand effect", showing, the effect of changing factor prices, $\hat{\mathbf{w}}$, on demand per unit, $l_{i, k}$ at initial sectoral output levels, and an output effect, which shows the impact of changing sectoral outputs, $g_{i, k}$, at given factor prices $\hat{\mathbf{w}} .^{22}$

For China, approximately 6.9 percentage points of the $8.0 \%$ increase in skilled labor can be attributed to the relative expansion of skilled labor intensive sectors. Specifically, it is a shift toward manufacturing and away from agriculture. ${ }^{23}$ Similarly for India, Table 7 shows that the changes in the sectoral output composition of the economy accounts for most of the change in skilled labor demand, with 19 percentage points of the long run $20 \%$ growth. Thus the economies adjust to world prices in the long-run primarily though changes in factor supplies and changes in the structure of production, particularly substitution away from agriculture and toward manufacturing. This last observation suggests that the liberalization of Agriculture, which employs the vast bulk of unskilled labor, is a key factor driving the results. This idea is pursued further in Section 6 .

[Insert Tables 6 and 7 about here]

\subsection{The Role of Agricultural Protection.}

The Stolper-Samuelson theorem tells us that changes in commodity prices will affect factor returns. Though the presumption is that import-competing sectors will usually be protected, this is not always supported by the facts. Anderson (2003), for example, reports average tariffs on Agriculture in low income countries of $20 \%$, which compares to high income countries tariffs on Agriculture of 16 percent and low income country tariffs on manufactured goods of just $12 \%$. In both China and India, agriculture also is either the most, or second most, protected sector as shown in Table 1.

\footnotetext{
${ }^{22}$ The factor price effect for each factor $k$ is $\sum_{i} \lambda_{i, k}\left(l_{i, k}^{\prime}-l_{i, k}\right) / l_{i, k}$, where $l_{i, k} \equiv \partial c(\hat{\mathbf{w}}) / \partial \hat{w}_{k}$ is the unit demand function, $\lambda_{i, k}$ is the share of sector $i$ in total output, and the prime denotes the counterfactual level. The output effect is $\left.\sum_{i} \lambda_{i, k}\left(l_{i, k}^{\prime} / l_{i, k}\right)\left(g_{i}^{\prime}-g_{i}\right) / g_{i}\right)$. These terms exhaust the total change in factor supply.

${ }^{23}$ Appendix B shows that the sectors which expand most significantly is the Low-Tech Manufacturing sector, which grows by $24 \%$, and Agriculture is the only traded sector to contract, falling $6.6 \%$.
} 
To assess the importance of agricultural tariffs, Table 8 reports the results for trade liberalization across all sectors except Agriculture. The results show that the impact effect on the skill premium is substantially reduced when the agricultural sector is excluded from the tariff elimination experiment. The impact on the skill premium falls from an increase of $1.7 \%$ to just $0.5 \%$ in the case of China and from $8.1 \%$ to $2.6 \%$ in the case of India. The evidence thus suggests that the agricultural tariffs are important in understanding the impact of trade liberalization on wage inequality in developing countries in the short run. The effects on skill labor deepening are also reduced, though less dramatically, with skilled labor rising by $5.2 \%$ in China and $12.3 \%$ in India. To explore the causes of these changes further we consider the role of KSC next.

\section{On-The-Job-Training \& K-S Complementarity.}

\subsection{Capital-Skill Complementarity.}

In all scenarios there is also significant capital deepening. This may also be a source of rising skill premiums given that the production functions in each sector are assumed to exhibit KSC. With positive KSC, the accumulation of physical capital will raise the marginal product of skilled labor by more than the marginal product of unskilled labor.

Stokey (1996), Tyers and Yang (2000), Krusell et al (2000) and Winchester and Greenaway (2007), among others, have cited capital skill complementarity as a source of wage inequality. The conclusion of these studies, however, is that wage inequality derives from technical change or investment market reforms however, and not trade liberalization per se. The issue of trade liberalization and $\mathrm{KSC}$, however, has not been widely explored.

The impact of $\mathrm{KSC}$ on equilibrium wages in a trade model, moreover, is not obvious. In a standard one-sector closed economy growth model, KSC means that capital accumulation will raise the marginal product of skilled labor and hence raise skilled wages relative to unskilled wages. For a standard small open economy model, however, the factor-price equalization theorem says that world commodity prices and zero profits completely determine factor prices, irrespective of the structure of the production functions. ${ }^{24}$ Hence capital accumulation will cause changes in the output structure, via the Rybczynski theorem, but have no effect on relative factor prices. Thus the intuition from the HeckscherOhlin model suggests that in an open economy, the degree of KSC may have no effect on the skill premium.

\footnotetext{
${ }^{24}$ Assuming that the country is producing inside the cone of diversification.
} 


\subsection{Measuring Capital-Skill Complementarity.}

A standard measure of KSC is the Allen elasticity of substitution, which measure the elasticity of the relative demand for a factor with respect to the rental prices. Given the unit cost function, described in (17) and (18), the difference in the parameters, $\nu-\sigma$, is proportional to the difference in the Allen elasticities of substitution for skilled and unskilled labor. ${ }^{25}$

In our benchmark calibration we take the elasticity of substitution parameters from Krusell et al (2000). They report $1-\sigma=12 / 3$ for the upper nest and $1-\nu=2 / 3$ for the lower nest, which are the values used in our base case results. ${ }^{26}$ To consider the impact of alternative degrees of KSC we hold the elasticity of substitution in the upper nest of the cost function, (17), constant at $1-\sigma=12 / 3$ and vary the value of the elasticity in the lower nest through $1-\nu \in\{1 / 3,2 / 3,12 / 3,3\} .{ }^{27}$ These values are shown in Table 8 . We label each "High", "Medium", "Zero" and "Substitutes" respectively, where "Medium" is the base case already discussed. Note that in the case "Zero" we have $\sigma-\nu=0$ which means that the cost functions are ordinary CES functions. Likewise in the "Substitutes" case we have $\sigma-\nu=0$.

[Insert Table 9 about here]

\subsection{Sensitivity to Capital-Skill Complementarity.}

Considering variations in KSC assumptions with both full and partial (excluding agriculture) liberalization requires comparing many variables across eight simulations. In order to focus on the key issues we consider the results on the supply of skilled labor and the skill premium, $w_{L S} / w_{L U}$. In addition, to gain some sense of the intermediate dynamics,

\footnotetext{
${ }^{25}$ Specifically KSC can be measured by the difference in the Allen elasticity of substitution for skilled and unskilled labor, $\sigma_{L S, k}-\sigma_{L U, k}=\left(1 / s_{k, i}\right) \partial \ln \left(L S_{i} / L U_{i}\right) / \partial \ln w_{k}$, for each capital type $k \in K$ in sector $i$. For our nested CES function this is given by $-\left(1 / s_{\theta}\right)(\nu-\rho)$ where $s_{\theta}$ is the share of the lower nest factors in total cost. An alternative concept is the Hicks elasticity of complementarity, which measures the partial effect of a change in factor supply on factor returns. The difference in the Hicks elasticities of complementarity for skilled and unskilled labor is proportional to $\sigma /(\sigma-1)-\nu /(\nu-1)$. Dropping sectoral subscripts, KSC can also be measured by the difference in the Hicks elasticities of complementarity $h_{L S, k}-h_{L U, k}, k \in K$. In terms of our cost function parameters this is $\left(1 / s_{k}\right) \partial \ln \left(w_{s} / w_{u}\right) / \partial \ln k=$ $-\left(1 / s_{\theta}\right)(\sigma /(\sigma-1)-\nu /(\nu-1))$. For a further discussion see Fallon and Layard (1974), Hamermesh (1993), Krusell et al (2000) and Duffy et al (2004).

${ }^{26}$ There is no single measure of the degree of capital skill complementarity in the literature. Krusell et al (2000) note that this makes results difficult to compare. Note also that we are using a cost function whereas Krusell et al (2000) use the production function.

${ }^{27}$ This implies a maximum value of $\sigma-\nu$ of 1.33 , which is substantially less than the one standard deviation in the estimate reported by Krusell et al (2000).
} 
we present the path of adjustment over the first 50 years. Thus the path of the skill premium and the stock of skilled labor for each value of $\nu$ are represented in Figure 1, for the full tariff elimination case, and in Figure 2 for the partial liberalization case.

Figure 1 shows that the degree of KSC assumed has a large effect on the behavior of the skill premium and the degree of skill accumulation. In both India and China however it can be seen that the rise in the skill premium does not depend on the existence of $\mathrm{KSC}$, as the skill premium also jumps on impact in the CES case. For example in China, where $\sigma-\nu=0$, the skill premium still jumps $1.5 \%$ on impact. In India the jump is approximately $2.5 \%$. Nevertheless these values are much smaller than the base case.

[Insert Figure 1 about here]

The other main difference between the medium or base case and the CES case where there is no KSC, is that the accumulation of skilled labor is much smaller in the CES case. The reduction is in the order of $1 / 2$ in China and $1 / 3$ in India. In India in particular, the large quantity of capital accumulation over the transition means that the accumulation of skilled labor ranges from approximately $20 \%$ in the high case to $-5 \%$ in the low case.

This difference in steady-state skilled labor stocks is one of the main factors affecting the size of the investment jump on impact and hence the size of the jump in the skill premium. Thus it can also be seen that these impact results are quite sensitive to the value of KSC assumed. Unlike the Heckscher-Ohlin, model where factor returns are insensitive to changes in endowments, we see that there are large increases in the skill premium over the transition when KSC is high. In particular, in the High case for India, the skill premium jumps by $24 \%$ on impact.

Thus it is evident that both KSC and the level of agricultural protection are sources of the rise in the skill premium. If either $\sigma=\nu$ or agricultural tariffs are held constant, the impact effect on the skill premium is substantially diminished. Moreover, Figure 3 shows the effect of combining these two counterfactuals. It reports the results for different degrees of KSC, when agricultural tariffs are held constant. With no agricultural tariff removal, and with CES production functions, $\sigma=\nu$, the impact on the skill premium is shown to be very small - less than $0.5 \%$ for China and is in fact negative in the case of India. Thus together, the high levels of agricultural protection and KSC can account for most of the observed rising skill premium in these experiments. ${ }^{28}$

\footnotetext{
${ }^{28}$ Our analysis suggests that falling trade costs, insofar as it alters traded goods prices, may also have large impacts on wage inequality and human capital accumulation.
} 


\subsection{The Skill Premium and On-The-Job Training Costs.}

The jump in the skill premium on impact can, in part, be understood as a StolperSamuelson type effect, with tariff reductions on agriculture driving the rise in the skill premium.In particular the agricultural sector is by far the largest share and absolute number of unskilled workers. This is not the whole explanation, however, since even when we exclude agriculture from liberalization, the jump in the skill premium is very large when KSC is high. In this section we show that the jump in the skill premium is also due to an increase in education investment demands and their impact on on-the-job training costs.

As noted above, the rise in demand for education on impact is greater for higher levels of KSC, since this induces more skilled labor accumulation. Thus there is a jump in the asset prices for skilled labor on impact due to the rise in expected future rentals from skilled labor. From equation (8) the rise in asset prices stimulates the increase in education enrollments, $H_{t}$.

The jump in education demand, however, also generates a proportional increase in the flow of graduates entering the labor market, $E_{t}=H_{t} / \zeta$. This in turn increases on-the-job training costs and, as can be seen in (5), reduces the stock of skilled labor available for production. This impact effect of education demand on on-the-job training costs can be seen in Figures 1 and 2 where the net supply of skilled labor falls on impact.

Thus higher degrees of KSC result in larger falls in the net supply of skilled labor on impact. Moreover, a higher degree of KSC results from smaller values of the Allen elasticity of substitution in the lower nest, $1-\nu$. This low elasticity raises the elasticity of the skill premium with respect to the supply of skilled labor, (which is approximately equal to $1 /(\nu-1)$ ). Thus a higher degree of KSC also raises the responsiveness of the skill premium to given reductions in the supply of skilled labor. ${ }^{29}$

Thus the results point to a potentially important dynamic link, between wage inequality and trade liberalization and KSC, that has not been discussed in the trade-wage literature. That is the impact of jumps in education flows on on-the-job training and the implied fall in the net supply of skilled labor. We have shown that with a high degree of KSC, these effects can potentially be very large. For India and Chian, this effec, com-

\footnotetext{
${ }^{29}$ To be more specific, consider the case of India. The fall in the available stock of skilled labor on impact is $-3.9 \%$ in the "Base" case and $-8.2 \%$ in the "High" case. The aggregate elasticity of the skill premium with respect to the supply of skilled labor in a one sector closed economy model is $\partial \ln \left(w_{L S} / w_{L U}\right) / \partial \ln L S=\left(s_{L S} / s_{\theta}\right)[\sigma /(\sigma-1)-\nu /(\nu-1)]+1 /(\nu-1)$, where $s_{L S} / s_{\theta}$ is the cost share of skilled labor in the lower CES nest. Given a value of $s_{L S} / s_{\theta}=0.03$, which is the aggregate value for India, this equates to an elasticity of 24.0 for the high case and 5.7 in the base case.
} 
bined with high levels of agricultural protection, means that tariff reforms can generate substantial increases in the wage inequality.

\subsection{Sensitivity to the On-The-Job Training Cost Function.}

To explore this idea further, Figure 3 presents the results for alternative values of adjustment parameter for the on-the-job training costs, $\beta_{e}$ in equation (5). The value of this parameter in the base case corresponds to a half life of ten years. Figure 3 shows the effects on the skill premium and skilled labor stock, when this value is halved and doubled respectively. This corresponds to half-lives for the skilled labor stock of around 6 and 18 years respectively. ${ }^{30}$

It can be seen that changing the cost of on-the-job training in this way does not have a large effect on the skill premium on impact. The main effect of the higher value is to cause a minor reduction in the jump on impact but causes the skill premium to rise for longer over the transition. Likewise a reduction in the adjustment costs has little impact on the impact effect of trade liberalization, but the initial rise in the skill premium decays faster.

The conclusion that the skill premium jumps on impact is robust to these changes. With larger adjustment costs the jump is slightly smaller, but the skill premium rises for several years before declining. With smaller adjustment costs, the economy adjusts faster so that the initial jump is larger, but the skill premium falls faster.

\section{Conclusion.}

An extensive literature on the effects of trade liberalization exists with respect to its impacts on poverty rates and wage inequality. Standard treatments of these issues take factor supplies as given and hence they also necessarily neglect the effects of trade on returns to education and the incentives for skill and capital accumulation. In this paper we develop a calibrated dynamic model of trade and growth with the aim of quantifying these dynamic benefits. The model is calibrated to Chinese and Indian data. We solve the full transitional path for the economy following unilateral trade liberalization experiments in each country.

\footnotetext{
${ }^{30}$ The half-life is calculated numerically by solving the model with a $10 \%$ shock to the initial stock of skilled labor.
} 
The key finding is that in both regions, the transitional dynamics of trade liberalization require a large jump in the skill premium on impact. This jump reflects not only the Stolper-Samuelson type effects of commodity price changes on wages for given endowments, and high initial tariff levels in agriculture, but also the effects of jumps in education demand on on-the-job training costs and the net skilled labor supply.

Since these impact effects depend on the expected future paths of all asset prices and capital stocks, they cannot be captured by short run static models, long run steady state models or models without forward looking behavior. This is not only a neglected aspect of trade-wage literature but we have also shown that it offers new insights into the relations between trade liberalization and wage inequality.

From a policy perspective we find that, in China and India, unilateral trade liberalization leads to large positive jumps in the skill premium on impact generating an increase in wage inequality. Nevertheless we also find that trade liberalization generates strong growth in skilled and unskilled wages. Thus despite the rise in wage inequality, trade liberalization is found to be "pro-poor" and also generates significant up-skilling of the labor force in each country. 
A Appendix: Additional tables.

[Insert Tables A1 and A2 about here] 


\section{References}

Arbache, Jorge Saba, Andy Dickerson and Francis Green, (2004) "Trade Liberalisation and Wages in Developing Countries", The Economic Journal, 114, 493, F73-F96.

Abrego, Lisandro and John Whalley, (2000) "The Choice of Structural Model in TradeWages Decompositions", Review of International Economics, 8, 3, 462-77.

Abrego, Lisandro and John Whalley, (2003) "Goods Market Responses to Trade Shocks and Trade and Wages Decompositions", The Canadian Journal of Economics, 36, 3, 747-757.

Abrego, Lisandro and T. Huw Edwards, (2002) "The Relevance of the Stolper-Samuelson Theorem to the Trade and Wages Debate", Centre for the Study of Globalisation and Regionalisation (CSGR), Working Paper No 96/02, University of Warwick.

Acemoglu, D., (2003) "Patterns of Skill Premia", Review of Economic Studies, 70, 199230.

Aghion, Philippe, Robin Burgess, Stephen Redding, and Fabrizio Zilibotti, (2006) "The Unequal Effects Of Liberalization: Evidence From Dismantling The License Raj In India", NBER Working Paper 12031.

Anderson, Kym (1994) "Food Price Policy In East Asia", Asian-Pacific Economic Literature, 8, 2, 15-30.

Anderson, Kym, (2003) "Trade Liberalization, Agriculture and Poverty in Low Income Countries", WIDER Discussion Paper, 2003/25.

Anderson, Kym, Jikun Huang, and Elena Ianchovichina, (2002) "Long-run Impacts of China's WTO Accession on Farm-Nonfarm Income Inequality and Rural Poverty", Paper presented at the World Bank Conference on China's WTO Accession, Policy Reform and Poverty Alleviation, Beijing, 28-29 June.

Baldwin, Richard and Frderic Robert-Nicoud, (2006) "Offshoring and Globalisation: What is New about the New Paradigm?", Graduate Institute of International Studies, Geneva; London School of Economics 24.

Baldwin, Richard. E., (1992) "Measurable Dynamic Gains from Trade", The Journal of Political Economy, 100, 1, 162-174.

Barro, R. J. and J. W. Lee, (2001) "International data on Educational Attainment: Updates and Implications", Oxford Economic Papers, 53, 3, 541-563. 
Barron, J., M. Berger, and D. Black, (1999) "Do Workers Pay for On-the Job Training", Journal of Human Resources, 34, 2, 235-252.

Becker, Gary S., (1962) "Investment in Human Capital: A Theoretical Analysis", The Journal of Political Economy, 70, S5, 9-49.

Behrman, J., N. Birdsall and M. Szekely, (2000) "Economic Reform and Wage Differentials in Latin America", Washington, StateDC: Inter-American Development Bank, IADB Working Paper 435.

Berman Eli, John Bound, and Zvi Griliches, (1994) "Changes in the Demand for Skilled Labor within U.S. Manufacturing Industries: Evidence from the Annual Survey of Manufacturing", Quarterly Journal of Economics, 109, 2, 367-397.

Bishop, J.M., (1991) On-The-Job Training of New Hires. In: Stern, David and Ritzen, Josef M.M (Eds), Market failure in Training? New Economic Analysis and Evidence on Training of Adult Employees, Springer Berlin.

Bond, Eric W., Kathleen Trask, and Ping Wang, (2003) "Factor Accumulation and Trade: Dynamic Comparative Advantage with Endogenous Physical and Human Capital", International Economic Review, 44, 3, 1041-1060.

Brown, Drusilla. K. and Robert M. Stern, (2001) "Measuring and Modelling the Effects of Trade and Investment Barriers in Services", Review of International Economics, 9, 2, 262-286.

Chamarbagwala, Rubiana, (2006) "Economic Liberalization and Wage Inequality in India," World Development, 34, 12, 1997-2015.

Chaudhuri, Shubham and Martin Ravallion, (2007) Partially Awakened Giants: Uneven Growth in China and India. In: Winters, L. A. and Yusuf, Shahid (Eds), Dancing With Giants: China, India, And The Global Economy, The World Bank, Washington StateDC. Das, Satya P., (2001) "Trade and Relative Wages: The Role of Supervisory Function by Skilled Workers", European Economic Review, 45, 1, 45-65.

Das, Satya P., (2006) "Trade, Skill Acquisition and Distribution", Journal of Development Economics, 81, 1, 118-141.

Deardorff, Alan, (2000) "Policy Implications of Trade and Wage Debates", Review of International Economics, 8, 3, 478-96.

Dimaranan, Betina V., (2006). Global Trade, Assistance, and Production: The GTAP 6 
Data Base. Center for Global Trade Analysis, Purdue University.

Dixon, P. B., B. R. Parmenter, A. A. Powell, (1992). Notes and Problems in Applied General Equilibrium Economics. North Holland.

Dollar, David and Aart Kray, (2002) "Growth is Good for the Poor", Journal of Economic Growth, 7, 3, 195-225.

Duffy, John, Chris Papageorgiou, and Fidel Perez-Sebastian (2004) "Capital-Skill Complementarity? Evidence From A Panel Of Countries", The Review of Economics and Statistics, 86,1, 327-344.

Dutta, P., (2005) "Accounting for Wage Inequality in India", Poverty Research Unit at Sussex, Department of Economics, University of Sussex, Working Paper No. 29.

Edmonds, Eric V., Nina Pavcnik, and Petia Topalova, (2007) "Trade Adjustment And Human Capital Investments: Evidence From Indian Tariff Reforms", NBER Working Paper 12884.

Fallon, P.R. and P.R.G. Layard, (1975) "Capital-Skill Complementarity, Income Distribution and Output Accounting", Journal of Political Economy, 83, 2, 279-302.

Falvey, Rod, David Greenaway, and Joana, Silva., (2007) "Trade Liberalisation and Human Capital Adjustment", Leverhulm Centre Research Paper, 34.

Feenstra, R.C. and G.H. Hanson, (1999) "The Impact of Outsourcing and High-Technology Capital on Wages: Estimates for the United States, 1979-1990", Quarterly Journal of Economics, 114, 3, 907-940.

Findlay, R. and H. Kierzkowski, (1983), "International Trade and Human Capital: A Simple General Equilibrium Model", Journal of Political Economy, 91, 6, 957-978.

Fleisher, Belton and Xiaojun Wang, (2004) "Skill Differentials, Return to Schooling and Market Segmentation in a Transition Economy: The Case of Mainland China", Journal of Development Economics, 73, 1, 315-328.

Goldberg, Pinelopi Koujianou and Nina Pavcnik, (2007) "Distributional Effects of Globalization in Developing Countries," Journal of Economic Literature, 45, 1, 39-82.

Hamermesh, Daniel S., (1993) Labor Demand, 2nd ed. Princeton University Press, Princeton.

Harrison, Glenn W., Thomas F. Rutherford, and David G. Tarr, (2003) "Trade Liberalization, Poverty and Efficient Equity", Journal of Development Economics, 71, 1, 
$97-128$.

Harrison, Glenn W., Thomas F. Rutherford, David G. Tarr, and Angelo Gurgel, (2004) "Trade Policy and Poverty Reduction in Brazil", The World Bank Economic Review, 18, $3,289-317$.

Helpman, Elhanan and Antonio Rangel, (1999) "Adjusting to a New Technology: Experience and Training", Journal of Economic Growth, 4, 4, 359-383.

Hertel, T.W., M. Ivanic, P.V. Preckel, and J.A.L. Cranfield, (2003) "Trade Liberalization and the Structure of Poverty in Developing Countries", GTAP Working Paper No. 25.

Hertel, T.W., M. Ivanic, P.V. Preckel, and J.A.L. Cranfield, (2004) "The Earnings Effects of Multilateral Trade Liberalization: Implications for Poverty", World Bank Economic Review, 18, 2, 205-36.

Ianchovichina, Elena and Will Martin, (2004) "Impacts of China's Accession to the World Trade Organization", The World Bank Economic Review, 18, 1, 3-27.

Kapur, Devesh and Pratap Bhanu Mehta, (2007) "Indian Higher Education Reform: From Half-Baked Socialism To Half-Baked Capitalism", Paper presented at the BrookingsNCAER India Policy Forum, New Delhi, July 2.

Katz, Lawrence F. and David Autor, (1999), Changes in the Wage Structure and Earnings Inequality. In: Ashenfelter (Ed) Handbook of Labor Economics, 3A, Elsevier.

Kijima, Yoko, (2006) "Why did Wage Inequality Increase? Evidence from Urban India 1983-99", Journal of Development Economics, 81, 1, 97-117.

Krugman, Paul, (2008) "Trade and Wages Reconsidered", Paper presented at the Brookings Panel on Economic Activity, February.

Krusell, Per, L. Ohanian, Jos-Vctor Ros-Rull, and Giovanni Violante, (2000) "CapitalSkill Complementarity and Inequality", Econometrica, 68, 1029-1053.

Lawrence, Robert, (2008) Blue-Collar Blues: Is Trade to Blame for Rising US Income Inequality?. Washington, StateDC: the Petersen Institute for International Economics.

Lawrence, Robert Z. and Matthew J. Slaughter, (1993) "International Trade and American Wages in the 1980's: Giant Sucking Sound or Small Hiccup?", Brookings Papers on Economic Activity, 1993, 2, 161-226.

Li, Yao, John Whalley, Shunming Zhang, and Xiliang Zhao, (2008) "The Higher Educational Transformation of China and Its Global Implications", NBER Working Paper 
13849.

Long, Ngo Van, Raymond Riezman, and Antoine Soubeyran, (2007) "Trade, Wage Gaps, and Specific Human Capital Accumulation", Review of International Economics, 15, 1, 75-92.

Mincer, Jacob, (1962) "On-the-Job Training: Costs, Returns, and Some Implications", The Journal of Political Economy, 70, S5, 50-79.

Mincer, Jacob, (1994) "Investment in U.S. Education and Training", NBER Working Paper 4844.

Mishra, Prachi and Utsav Kumar, (2005) "Trade Liberalization and Wage Inequality: Evidence From India", IMF Working Paper wp0520.

OECD (2002) Education at a Glance Indicators. OECD Publishing:Geneva.

Press W.H., B.P. Flannery, S.A. Teukolsky, and W.T. Vetterling, (1990) Numerical Recipes: The Art of Scientific Computing. Cambridge University Press.

Ravallion, Martin, and Shaohua Chen, (2003) "Measuring Pro-Poor Growth", Economics Letters, 78, 1, 93- 99.

Richardson, J. David, (1995) "Income Inequality and Trade: How to Think, What to Conclude" The Journal of Economic Perspectives, 9, 3, 33-55

Schultz, T. W., (1960) "Capital Formation by Education", Journal of Political Economy, $68,6,571-83$.

Slaughter, Matthew J, (1999) "Globalization and Wages: A Tale of Two Perspectives", The World Economy, 22, 5, 609-629.

Stokey N.L., (1996) "Free Trade, Factor Returns, and Factor Accumulation", Journal of Economic Growth, 1, 4, 421-447.

Trimborn, Timo, Karl-Josef Kocha, and Thomas M. Steger, (2008) "Multidimensional Transitional Dynamics: A Simple Numerical Procedure", Macrodynamics, 12, 3, 301-319.

Tyers, Rod, and Y. Yang, (2000) "Capital-skill Complementarity and Wage Outcomes Following Technical Change in a Global Model", Oxford Review of Economic Policy, 16, $3,23-41$.

UNESCO, (2008) UNESCO Institute for Statistics. Available at: < http://www.uis.unesco.org/> . Accessed July 2008. 
Wilcoxen, Peter J., (1988) "The Effects Of Environmental Regulation And Energy Prices On US Economic Performance", PhD Thesis, Harvard University.

Winchester, Niven, (2007) Trade and Rising Wage Inequality: What can We Learn from a Decade of Computable General Equilibrium Analysis? In: D. Greenaway, R. Upward and P. Wright (Eds), Globalisation and Labor and Market Adjustment. Palgrave Macmillan World Bank (2008), World Development Indicators, World Bank, Washington DC.

Winchester, Niven and David Greenaway, (2007) "Rising Wage Inequality and CapitalSkill Complementarity", Journal of Policy Modeling, 29, 1, 41-54.

Winters, L. Alan., N. McCulloch, and A. McKay, (2004) "Trade Liberalization and Poverty: The Evidence So Far", Journal of Economic Literature, 42, 1, 72-115.

Winters, L Alan, (2004) "Trade Liberalisation and Economic Performance: An Overview", The Economic Journal, 114, 493, F4-F21.

Wood, Adrian and Michele Calandrino, (2001) "When the Other Giant Awakens", Economic and Political Weekly, 35, 52.

Yusuf, Shahid, Kaoru Nabeshima, and Dwight H. Perkins, (2007) China and India Reshape Global Industrial Geography. In: Winters, L. A. and Yusuf, Shahid (Eds), Dancing With Giants: China, India, And The Global Economy. The World Bank, Washington StateDC. 
Figure 1: Capital-Skill Complementarity

(i) Skill Premium - China

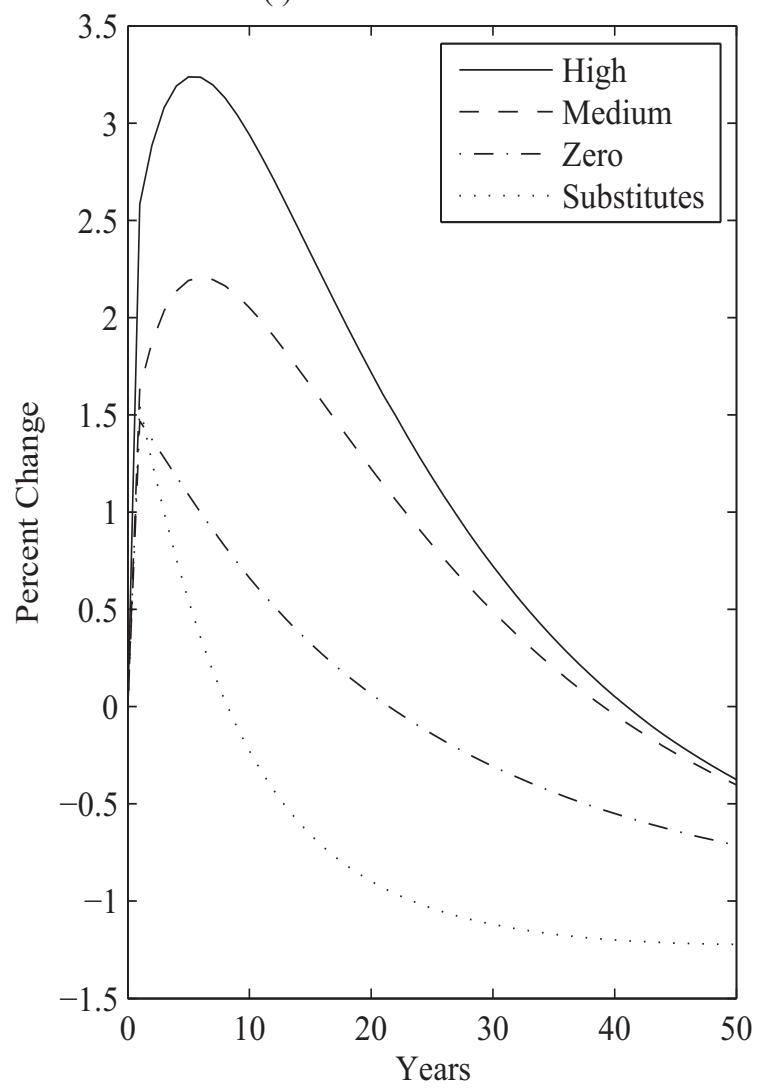

(i) Skill Premium - India

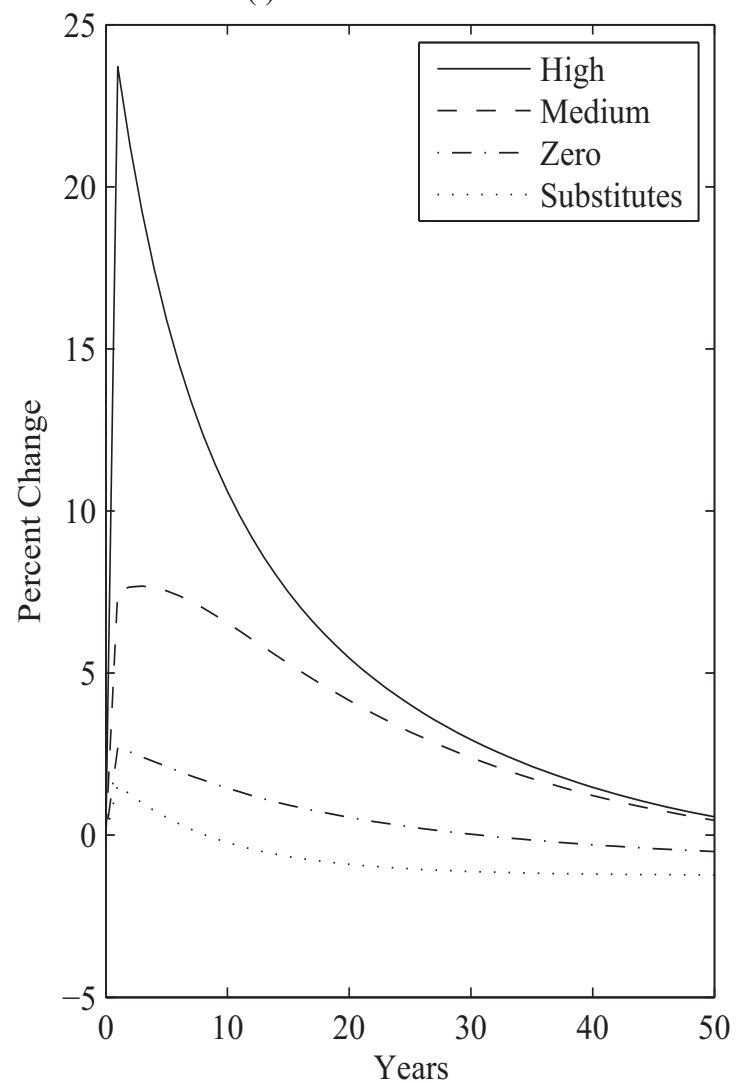

(ii) Skilled Labour Stock - China

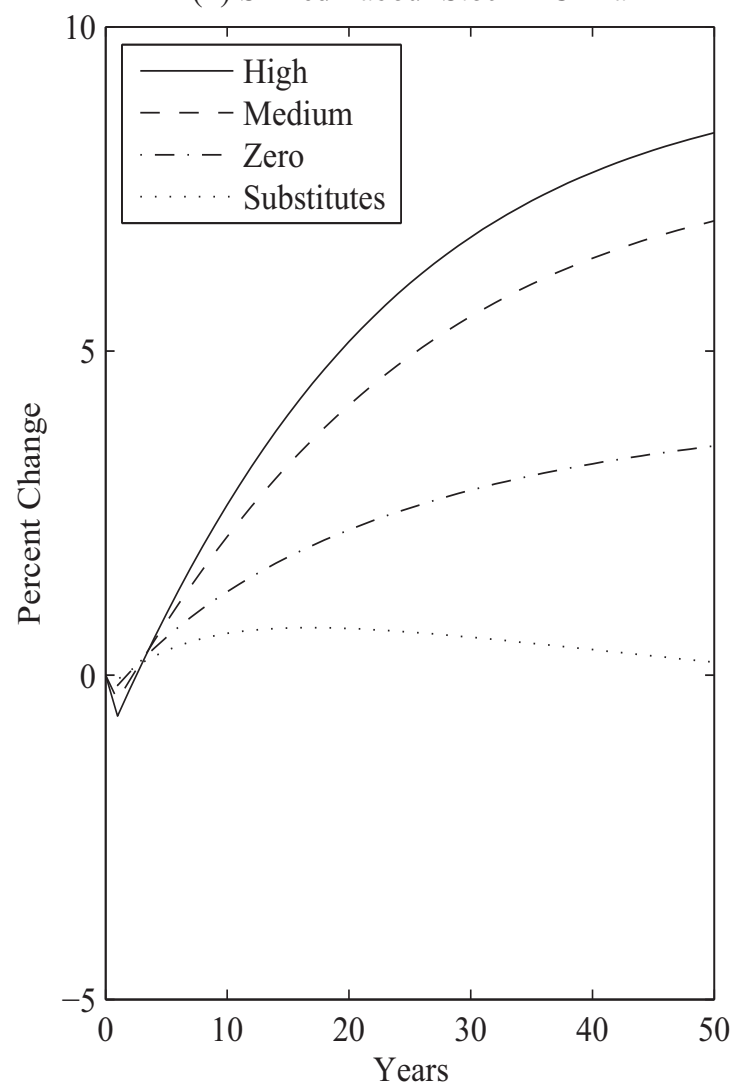

(ii) Skilled Labour Stock - India

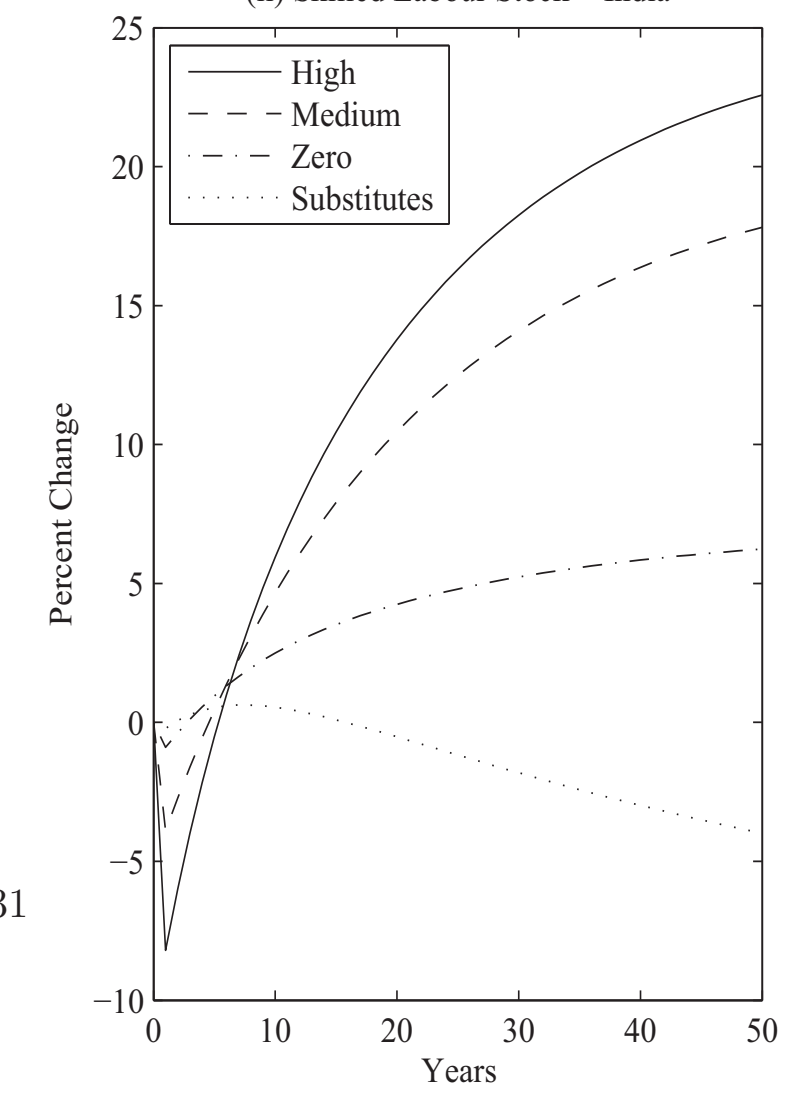


Figure 2: Capital-Skill Complementarity with No Agricultural Liberalization
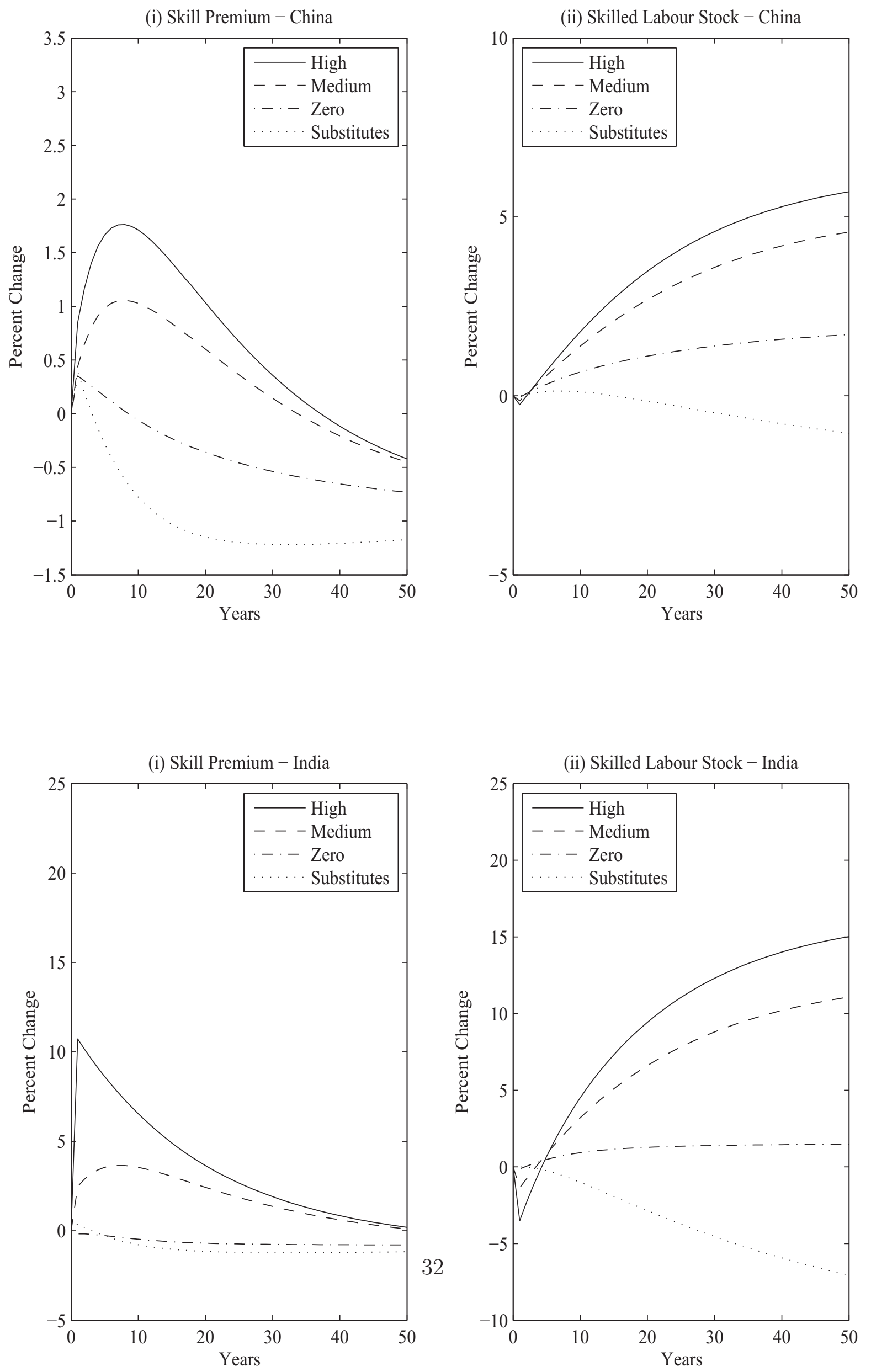
Figure 3: Sensitivity to On-the-job Training Cost Function Parameter

(i) Skill Premium - China

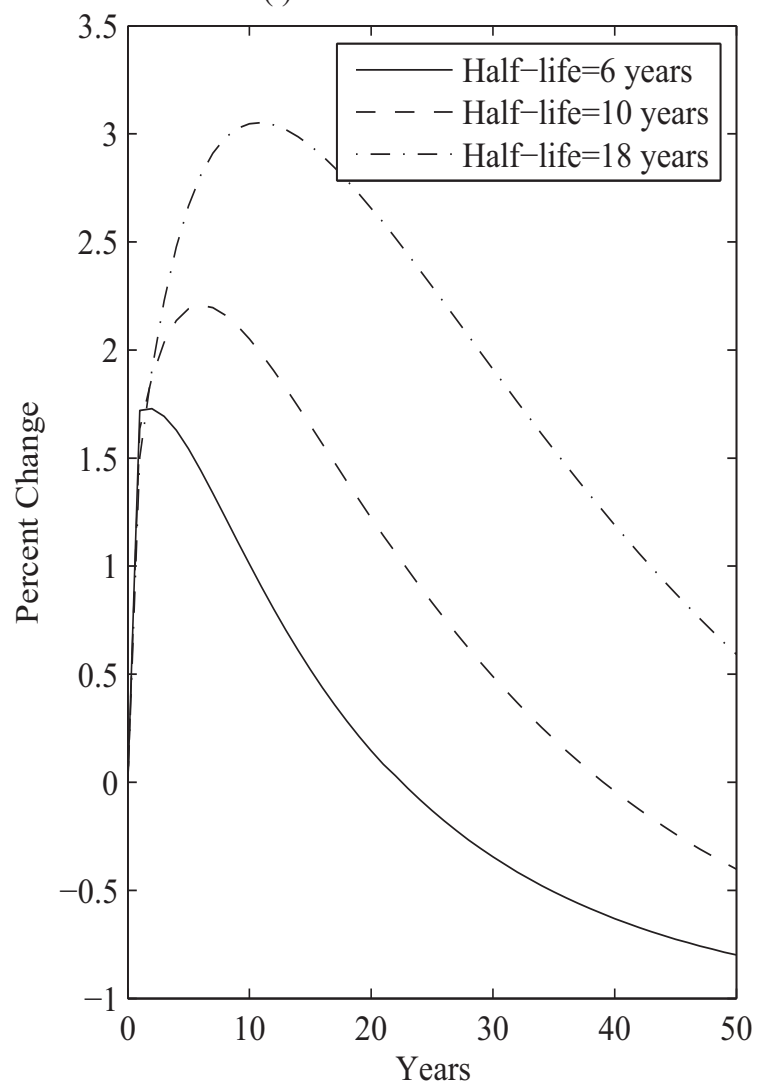

(i) Skill Premium - India

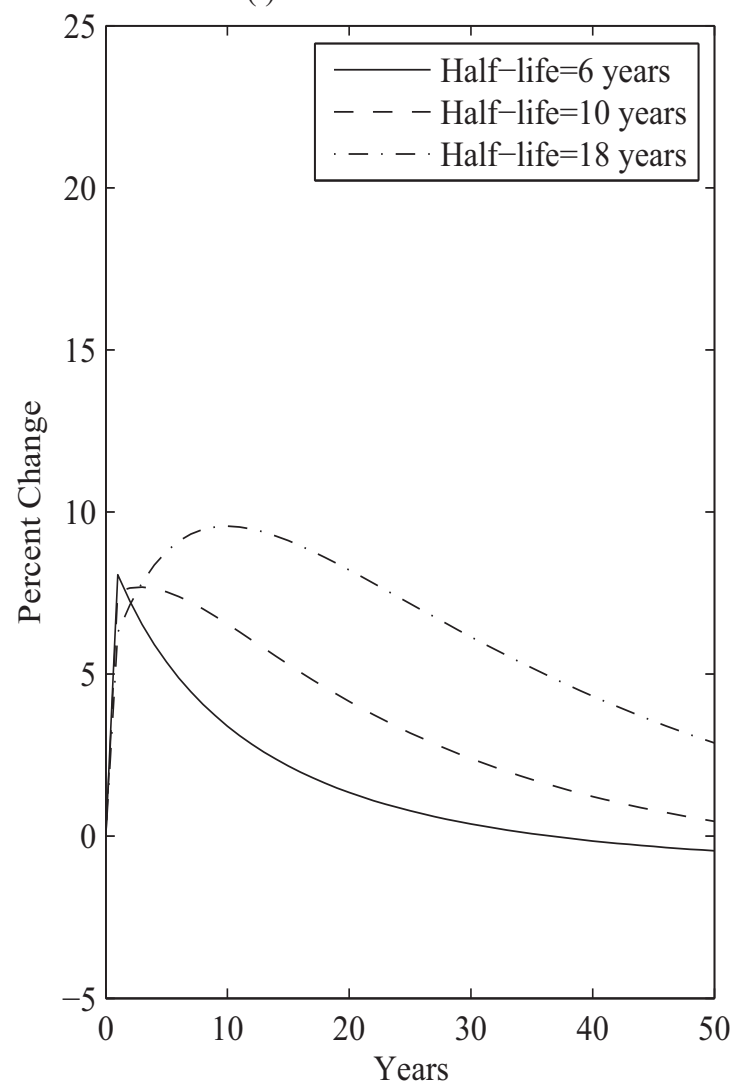

(ii) Skilled Labour Stock - China

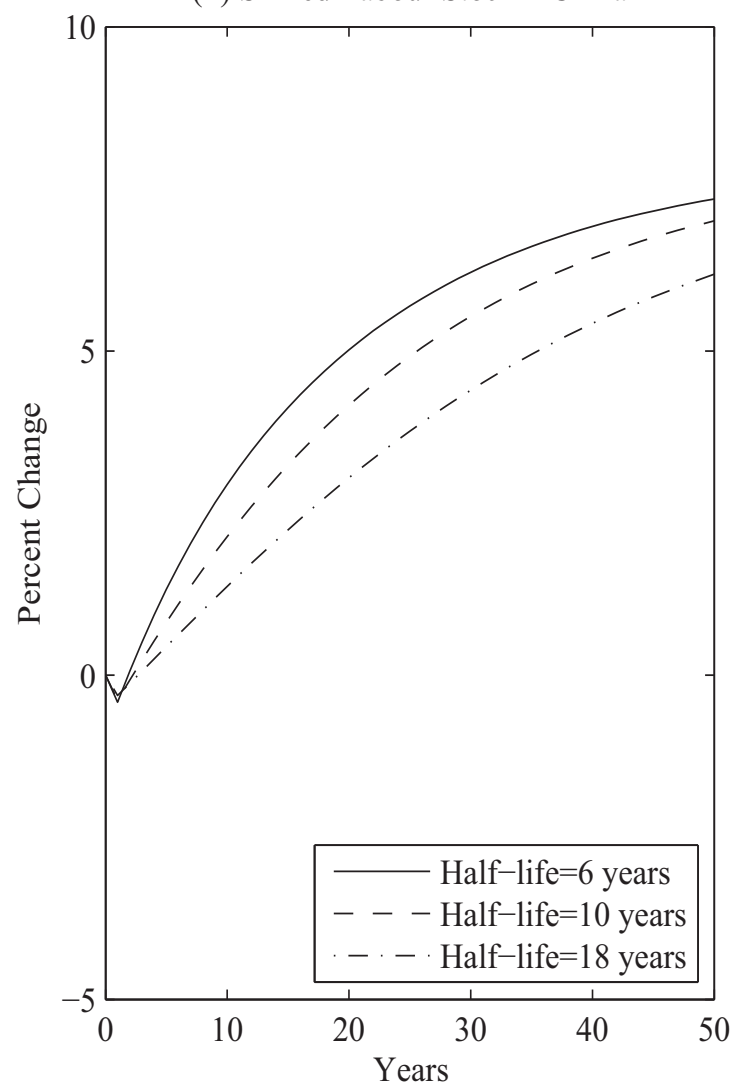

(ii) Skilled Labour Stock - India

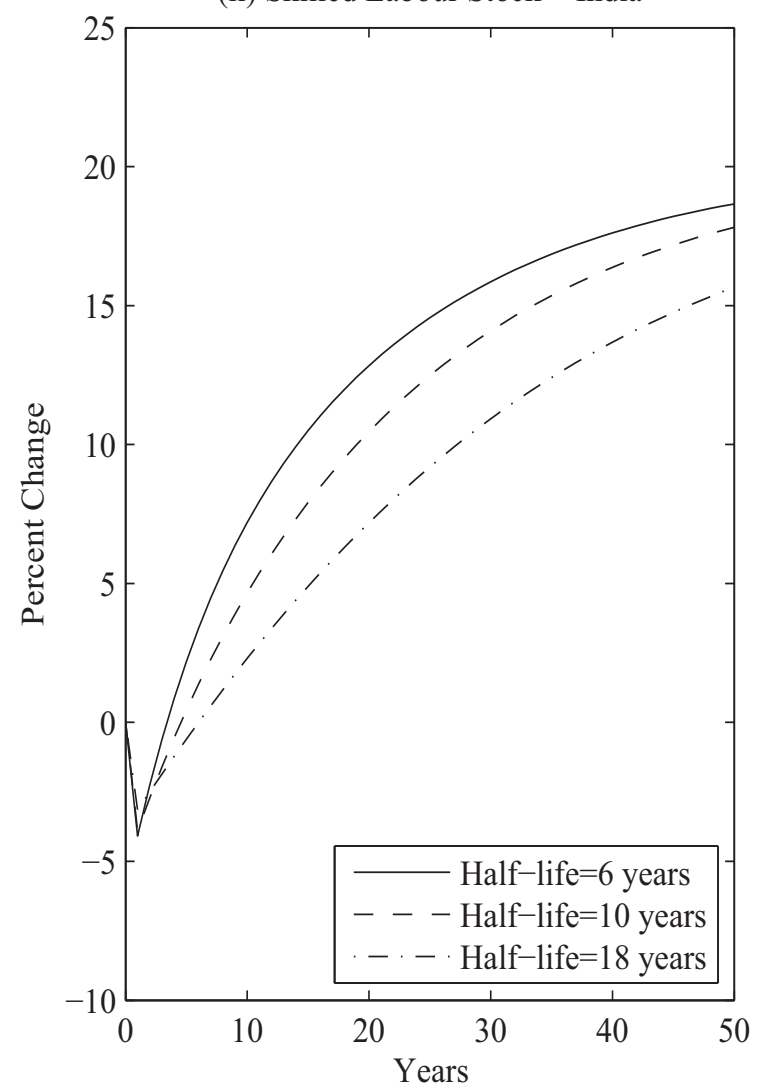




\section{Appendix B}

This appendix describes the model described in the text. The world economy consists of three regions. These are either USA, China and the Rest-of-World aggregate, or USA, India and the Rest-of-World $(R O W)$. In the $R O W$ outputs and prices are exogenous but the export supplies of commodities to other regions are endogenous. The non- $R O W$ regions can face an infinitely elastic demand for their exports from the $R O W$. There are eleven goods produced in 11 sectors denoted by the set $I=\{1, \ldots, 11\}$. Of these the first six elements are traded goods, $I_{T}=\{1, . ., 6\}$ and the last five are non-traded, $I_{N}=\{7, \ldots, 11\}$

\section{$1.1 \quad$ Technology}

Let $\bar{R}=\{1,2,3\}$ denote the three regions, where region 3 shall always refer to the $R O W$ region, and region 1 is always the USA. It will also be convenient to refer to the subset of regions that excludes the $\mathrm{ROW}, R=\{1,2\}$.

Firms in each non-ROW region, $R=\{1,2\}$, use intermediate goods and primary factors of production to produce a real gross output flow, $g_{i}^{r}$, in each industry $i$. Suppressing region superscripts, the inputs of the valued added aggregating vector are the elements of the set of factors, $\bar{K}=\{1, \ldots, 7\}$ where, respectively, $1=$ Machinery and Equipment, $2=$ Structures, $3=$ Residential Capital, $4=$ Skilled labor, $5=$ Unskilled labor, $6=$ Land, and $7=$ Resources. We label these factors $V_{k, t}, k \in \bar{K}$. The first three factors are all types of reproducible physical capital, and are denoted by the subset $K=\{1, \ldots, 3\}$, The sectoral allocation of these factors for each sector $i$ is likewise denoted as $V_{k, i, t}, k \in \bar{K}$. It will be also convenient to occasionally refer to aggregate skilled and unskilled labor endowments as $V_{4}=L S$ and $V_{5}=L U$.

As in standard growth models we assume that there is exogenous productivity growth associated with labor and other exogenously supplied factors. We denote the levels of factor augmenting productivity for factor $k$, at time $t$, as $A_{k, t}$.

Suppressing time subscripts, these effective and actual primary inputs are combined in a time independent value added function

$$
v_{i}=v_{i}\left(V_{1, i}, \ldots, V_{7, i}\right)
$$

These inputs are measured in effective units. Dual to this value added aggregator, $v_{i}$, is 
a cost function

$$
c_{i}=c_{i}(\hat{\mathbf{w}})
$$

where $\hat{\mathbf{w}}_{i}$ is the vector of returns $\hat{\mathbf{w}}_{i}=\left\{w_{1}, \ldots, w_{7}\right\}$, and the circumflex denotes effective units so that $\hat{w}_{k}=w_{k} / A_{k}, k \in K$. As noted in the text, we assume this cost function is a nested CES form.

Intermediate goods and the intermediate and value added aggregates are combined with fixed coefficients. Let $M_{i}$ denote an intermediate input aggregate in each industry $i$. Then

$$
M_{i}=\min _{j}\left[\frac{Y_{j, i}}{a_{j, i}}\right]
$$

where $a_{j, i}$ is a technological parameter and $Y_{j, i}$ is the quantity of good $j$ used as an input in sector $i$.

The real gross output flow $g_{i}$, in each industry $i$ is then

$$
g_{i}=\min _{i}\left[M_{i}, v_{i}\right]
$$

For the ROW region output is an exogenously growing "endowment", $V_{w, t}$, which grows at rate $V_{w, t+1} / V_{w, t}=1+\gamma$, where $\gamma$ is a constant. It follows, therefore, that on a steady state the non- $R O W$ regions must also be growing at rate $1+\gamma$.

\subsection{Commodity Supply}

In the non-traded goods industries gross output is simply a scalar. In the traded goods industries gross output is an aggregate of three destination specific goods - one good destined for the home market, and two others for the other respective export regions. Given the set of regions, $\bar{R}=\{1,2,3\}$, the gross output for traded good sector, $i$, is,

$$
g_{i}^{r}=g_{i}^{r}\left(x_{i}^{r, 1}, x_{i}^{r, 2}, x_{i}^{r, 3}\right)
$$

where $g_{i}^{r}, r \in \bar{R}$ is convex and linearly homogenous in its arguments and the $x_{i}^{r, j}$ refer to the supply of good $i$ from region $r$ to region $j \in \bar{R}, r \in \bar{R}$. Dual to these grows output functions are the revenue functions given by,

$$
\phi_{i}^{r}\left(p_{i}^{r, 1}, p_{i}^{r, 2}, p_{i}^{r, 3}\right) g_{i}^{r}
$$


for $r \in \bar{R}$, where the $p_{i}^{r, j}$ are producer prices for firms in region $r$ received in each market, $j$. Since goods in each market are homogenous, irrespective of the source region, the producer price for a firm in each region $r$ selling in region $j$, must satisfy the conditions $p_{i}^{r, j}\left(1+\tau^{j, r}\right)=q_{i}^{j}$ where $\tau^{j, r}$ are the tariff rates by region $j$ on each region $r$ 's exports. ${ }^{1}$ The revenue function is assumed to be of the Constant Elasticity of Transformation (CET) form.

The regional supply functions are obtained from this revenue function using the envelope theorem. For the non-ROW regions, $R=\{1,2\}$, the unit supply functions to each are equal to $x_{i}^{r, j}=\left(\partial \phi_{i}^{r} / \delta p_{i}^{r j}\right) g_{i}^{r}$. For $r \neq j$ these unit supply functions are export supply functions. For the ROW region $x_{i}^{3 j}=\left(\partial \phi_{i}^{3} / \delta p_{i}^{3 j}\right) \psi V_{W}$, for $j \in R$ where $\psi$ is a parameter that scales exports proportionally to world GDP.

\subsection{Commodity Demands}

Given the Leontief technology for intermediate goods, intermediate demands for each sector $i$, and each region $R \in\{1,2\}$, are given by,

$$
\sum_{j} a_{i, j}^{r} g_{j}^{r}
$$

Final demands for each commodity, except education services, are determined by several CES aggregate expenditure functions. There are two agents in each region, a government and a representative household. The households make education and investment decisions as well as consume. The set of final goods spending is given by $Z=\{1, \ldots, 5\}$ where elements $1 . . .3$ represent investment spending on three three types of physical capital, 4 represents consumption spending and 5 is Government spending. For each spending type in each region, there is a constant elasticity of substitution (CES) unit expenditure index function, given by,

$$
e_{z}^{r}\left(\mathbf{q}^{r}\right)
$$

where $\mathbf{q}^{r}$ is the vector of consumer prices for each region. Shepherd's Lemma gives a vector of commodity demands generated by each component of final demand

$$
d_{z, i}^{r}=\frac{\partial e_{z}^{r}}{\partial q_{i}^{r}} Q_{z}^{r}
$$

\footnotetext{
${ }^{1}$ For clarity this ignores commodity taxes which are included in the model.
} 
where $Q_{z}^{r}$ is the real quantity index for each of these spending types. Thus $Q_{z}^{r} e_{z}^{r}$ is the total spending on each element of the list of spending types $z$. For the subset of spending types that that refer to investment spending $z \in\{1,2,3\}$, the value of $e_{z}^{r}$ determines the investment price index.

\subsection{Aggregate Investment demand}

Except for government spending, the level of spending on each type of investment is determined through inter-temporal maximization decisions by households. Investment spending is determined by households who choose an optimal investment plan to maximize the net present value of the rental stream of the asset, given an adjustment cost function $C\left(Q_{k}^{r}, V_{k}^{r}\right), k \in K$.

The investment plan is the solution to the Fisher problem of choosing a sequence of gross investment spending to maximize the Lagrangian

$$
\begin{array}{r}
L_{k}^{r}=\sum_{t=0}^{\infty}\left(\frac{1}{1+\rho}\right)^{t}\left[u_{k, t} V_{k, t}^{r}-u_{k, t} C_{k}^{r}\left(Q_{k, t}^{r}, V_{k, t}^{r}\right)-e_{k, t}^{r} Q_{k, t}^{r}\right. \\
\left.-\Pi_{k, t+1}^{r}\left(V_{k, t+1}^{r}-Q_{k, t}^{r}-\left(1-\delta_{k}\right) V_{k, t}^{r}\right)\right]
\end{array}
$$

where $k \in K, e_{k}^{r}$ are the investment cost indices and $u_{k}^{r}$ refer to after factor tax rentals on physical capital $k$ in region $R$. Assuming quadratic adjustment costs

$$
C_{k}^{r}\left(Q_{k, t}^{r}, V_{k, t}^{r}\right)=\frac{\beta_{k,}^{r}\left(Q_{k, t}^{r}-(\delta+\gamma) V_{k, t}^{r}\right)^{2}}{V_{k, t}^{r}}
$$

where $b_{k}$ is a parameter, $g$ is the steady state growth rate of the economy, $\delta_{k}$ is the retirement rate for skilled labor, we obtain an investment demand equation for each asset type $k$, as

$$
\frac{Q_{k, t}^{r}}{V_{k, t}^{r}}=\frac{\Pi_{k, t}^{r}-e_{k, t}^{r}}{\beta_{k, t}^{r} u_{k, t}^{r}}+\gamma+\delta_{k}
$$

for $k \in K$. The Lagrange multipliers, $\Pi_{k, t}^{r}$, have the usual interpretation as the shadow price of a unit of capital of type $k$. For reference, the shadow price of the stock evolves according to the following dynamic equation,

$$
\Pi_{k, t}^{r}=\frac{1}{1+\rho}\left[\left(u_{k, t+1}^{r}-u_{k, t+1}^{r} C_{k, 2}^{r}\left(Q_{k, t+1}^{r}, V_{k, t+1}^{r}\right)+\left(1-\delta_{k}\right) \Pi_{k, t+1}^{r}\right]\right.
$$

where $C_{k, 2}^{r}\left(Q_{k, t+1}^{r}, V_{k, t+1}^{r}\right)$ refers to the derivative of the adjustment cost function with 
respect to the second argument, $V_{k, t+1}^{r}$. Finally note that the net capital stocks available for production are $\tilde{V}_{k, t}^{r} \equiv V_{k, t}^{r}-C_{k}^{r}\left(Q_{k, t}^{r}, V_{k, t}^{r}\right)$

\subsection{Aggregate Schooling Demand}

Households also make schooling decisions to augment their skilled labor supplies. At a point in time the labor force in each region, 1 and 2 consists of skilled workers $L S_{t}^{r}$, unskilled workers, $L U_{t}^{r}$, and those who are at school acquiring human capital, $H_{t}^{r}$, where $H_{t}^{r}=\zeta E_{t}^{r}$ and $E_{t}^{r}$ is the annual number of new graduates each of whom has attended school for $z$ years. The flow of graduates, or entrants, is therefore $E_{t}^{r}=H_{t}^{r} / \zeta$. We treat $E_{t}^{r}$ as a decision variable, which effectively means that the stock of students is also chosen optimally at each point in time.

As discussed in the text, schooling is purchased in a competitive market at price $q_{e, t}^{r}$. Total spending on education services is given by $H_{t}^{r} A_{e, t}^{r} q_{e, t}^{r}$ where $A_{e, t}^{r}$ is a technical parameter that represents the level of costs per student and $q_{e, t}^{r}$ is the consumer price for education, inclusive of education subsidies. We assume further that new graduates faces costs in entering the workforce due to on-the-job-training costs, which affects their productivity. This is captured by the on-the-job training cost function $J^{r}\left(H_{t}^{r}, L S_{t}^{r}\right)$. The maximization problem that defines the households schooling investment plan is

$$
\begin{gathered}
L_{H}^{r}=\sum_{t=0}^{\infty}\left(\frac{1}{1+\rho}\right)^{t}\left[u_{s, t}^{r} L S_{t}^{r}-u_{s, t}^{r} J^{r}\left(H_{t}^{r}, L S_{t}^{r}\right)+u_{u, t}^{r} L U_{t}^{r}-q_{e, t}^{r} A_{e, t}^{r} H_{t}^{r}\right. \\
\left.-\Pi_{e, t}^{r}\left(L S_{t+1}^{r}-L S_{t}^{r}-E_{t}^{r}+d L S_{t}^{r}\right)\right]
\end{gathered}
$$

where

$$
J^{r}\left(H_{t}^{r}, L S_{t}^{r}\right)=\frac{\beta_{e}^{r}\left(H_{t}^{r}-b \zeta L S_{t}^{r}\right)^{2}}{2 L S_{t}^{r}}
$$

The first order condition for $E_{t}^{r}$ gives a schooling demand equation for each region,

$$
\frac{H^{r}}{L S^{r}}=\frac{\Pi_{e, t}^{r}-u_{u, t}^{r}-q_{e, t}^{r} A_{e, t}^{r}}{\beta_{e}^{r} u_{L S, t}^{r}}+b \zeta
$$

where $b$ is the steady state birth rate.

The updating equation for $\Pi_{e, t}^{r}$ is

$$
\Pi_{e, t}^{r}=\frac{1}{1+\rho}\left(u_{L S, t+1}^{r}\left(1-J_{2}^{r}\left(H_{t+1}^{r}, L S_{t+1}^{r}\right)\right)-u_{L U, t+1}^{r}+(1-d) \Pi_{e, t+1}^{r}\right)
$$


We shall return to this expression later when describing the steady state and also the solution method. Again note that, due to on-the-job training costs the net skilled labor available for use in production at time $t$. The net capital stocks available for production is $\tilde{L} S_{t}^{r} \equiv L S_{t}^{r}-C_{k}^{r}\left(H_{t}^{r}, L S_{t}^{r}\right)$.

\subsection{GDP, Consumption and Government Spending}

Consumption spending is determined by a log run target debt to GDP ratio, and a consumption smoothing plan which minimizes deviations in consumption and net foreign assets from the long run target values. Here $G D P_{t}^{r}$ is defined simply as the sum of all net factor incomes, $G D P_{t}^{r}=\sum_{k \in K} w_{k} \tilde{V}_{k}^{r}+w_{L S}^{r} \tilde{L S}^{r}+w_{L U}^{r} L U^{r}+\sum_{j \in N} w_{j}^{r} V_{j}^{r}$.

Denote the consumption spending to GDP ratio as $\chi_{t}^{r}$. Then the solution to the consumer's optimization problem is;

$$
\chi_{t}^{r}=\bar{\chi}^{r}+\lambda^{r}\left(f_{t}^{r}-\bar{f}^{r}\right)
$$

for $r \in R$ where $\lambda^{r}$ is a parameter and $f_{t}^{r}$ and $\bar{f}^{r}$ are the current and target levels of net foreign assets to GDP ratio in region $R$. The derivation of this consumption function depends on the steady state debt targets and is explained further below. Equation (39) thus determines the level of consumption spending relative to factor income, $G D P_{t}^{r}$. Real consumption is obtained by dividing consumption spending, $\chi_{t}^{r} G D P_{t}^{r}$, by the consumption price index $e_{3}^{r}\left(q^{r}\right)$.

Government spending is assumed to be determined by a simple policy rule that fixes aggregate spending, $G_{t}^{r}$, as a proportion of aggregate GDP.

$$
G_{t}^{r} / G D P_{t}^{r}=\omega
$$

Given income taxes, tariffs and commodity taxes, an endogenous lump sum subsidy, lump $p_{t}^{r}$, ensures that the government budget is balanced at each point in time.

\subsection{Static Equilibrium}

In a static equilibrium at time $t$ the values of $\Pi_{k, t}^{r}$ and $\Pi_{k, t+1}^{r}$ are taken as given along with the endowment vectors $V_{k, t}^{r}$, consumption to GDP ratio $\bar{\chi}^{r}$, and debt to GDP ratio $\bar{f}_{t}^{r}$. Formally we have: 
Definition 1. A static equilibrium is a set of: consumer prices; $q_{i}^{r}$; factor prices, $w_{k}^{r}$; and gross outputs; $g_{i}^{r}$, for two regions, $R \in\{1,2\}$, which, for given values of $\Pi_{k}^{r}, \bar{c}^{r}, \bar{f}^{r}, V_{k}^{r}$ and world prices, $q_{i}^{3}$, satisfy:

zero profits;

$$
\phi_{i}^{r}=\sum_{j \in I} a_{j i}^{r} q_{j}^{r}-c_{i}^{r}(\mathbf{w}), i \in I, r \in R
$$

goods market clearing;

$$
\begin{gathered}
\phi_{i 1}^{1} g_{i}^{1}+\phi_{i 1}^{2} g_{i}^{2}+r_{i, 1}^{3} V_{i}^{3}=\sum_{j \in I} a_{i, j}^{1} g_{j}^{1}+a_{i, e}^{1} y_{e}^{1}+\sum_{z} d_{z, i}^{1} \quad i \in I_{T} \\
\phi_{i, 2}^{1} g_{i}^{1}+\phi_{i, 2}^{2} g_{i}^{2}+\phi_{i, 2}^{3} V_{i}^{3}=\sum_{j \in I} a_{i, j}^{2} g_{j}^{2}+a_{i, e}^{2} y_{e}^{2}+\sum_{z} d_{z, i}^{2} \quad i \in I_{T} \\
g_{i}^{r}=\sum_{j} a_{i, j}^{r} g_{j}^{r}+a_{i, e}^{r} y_{e}^{r}+\sum_{z} d_{z, i} \quad i \in I_{N}, \quad r \in R
\end{gathered}
$$

and factor market clearing;

$$
\begin{gathered}
V_{k}^{r}-C\left(Q_{k}^{r}, V_{k}^{r}\right)=\sum_{i \in I} \frac{\partial c_{i}^{r}}{\partial w_{k}} g_{i}^{r} \quad r \in R, k \in K \\
L S^{r}-J\left(H^{r}, L S^{r}\right)=\sum_{i \in I} \frac{\partial c_{i}^{r}}{\partial w_{L S}^{r}} g_{i}^{r} \quad r \in R \\
L U^{r}=\sum_{i \in I} \frac{\partial c_{i}^{r}}{\partial w_{L U}^{r}} g_{i}^{r} \quad r \in R \\
V_{k}^{r}=\sum_{i \in I} \frac{\partial c_{i}^{r}}{\partial w_{k}^{r}} g_{i}^{r} \quad k \in N, r \in R
\end{gathered}
$$

A static equilibrium thus consists of 22 zero profit conditions 22 commodity market clearing conditions and 14 factor market clearing conditions solving $2 \times 11$ commodity prices, $q_{i}^{r} ; 2 \times 7$ factor prices, $w_{k}^{r}$ and $2 \times 11$ gross outputs, $g_{i}^{r}$. In practice it is solved in Fortran using numerical methods described in Press et al (1990).

\subsection{Dynamics}

The dynamic path for the economy is described by the following equations of motion for $2 \times 8+1$ state variables. These are the 7 primary factors in each region, the population of each region and the world endowment. For each region $r \in R$ we have the updating 
equations (14) and (4).

$$
\begin{gathered}
V_{k, t+1}^{r}=Q_{k, t}^{r}+\left(1-\delta_{k}\right) V_{k t}^{r}, \quad k \in K \\
L S_{t+1}^{r}=L S_{t}^{r}(1-d)+H_{t}^{r} / \zeta
\end{gathered}
$$

Note further that given a static equilibrium (13) and (37) determine the aggregate investment demands, $Q_{k, t}^{r} k \in K$ and the stock of students $H_{t}^{r}$ in each non-ROW region. In addition the updating equations for the exogenous factors and population (labor force) are

$$
\begin{gathered}
V_{k, t+1}^{r}=V_{k, t}^{r}, \quad k \in N \\
P_{t+1}^{r}=(1+n) P_{t}^{r}
\end{gathered}
$$

For the Rest-of-World region we have an exogenously growing world endowment.

$$
V_{t+1}^{R O W}=(1+\gamma) V_{t}^{R O W}
$$

The consumption plan of agents was given in (39). This plan is derived from the assumption that the households minimize a loss function which depends on deviations of the consumption-asset path from the reference target steady state values. The loss function for $r \in R$, is

$$
V=\sum_{t=0}^{\infty} \frac{1}{(1+\rho)^{t}} L\left(\bar{\chi}^{r}-\chi^{r}, \bar{f}_{t}^{r}-f_{t}^{r}\right)
$$

where $L(\cdot)$ is a quadratic loss function around the target path $(\bar{\chi}, \bar{f})$. The solution is a lagged adjustment function given by (39) above.

Thus consumption at a point in time is increasing in the level of net foreign assets. To derive the long run consumption to GDP ratio we need to first describe the net foreign asset balance for each region. Net foreign assets evolve as

$$
F_{t+1}^{r}=\operatorname{surp}_{t}^{r}+(1+r) F_{t}^{r}
$$

where $\operatorname{surp}_{t}^{r}$ is the trade surplus for region $R$ at time $t$. Using the national accounting 
definition, substituting for $\operatorname{surp}_{t}^{r}$ and dividing by GDP at factor costs gives

$$
f_{t+1}^{r}=\left(\frac{1+\rho}{1+\gamma}\right) f_{t}^{r}+\alpha_{t}^{r}-\chi_{t}^{r}
$$

where $\alpha_{t}^{r}=1+\operatorname{tax}_{t}^{r}-\omega^{r}-$ invest $_{t}^{r}$, and tax and invest are total indirect taxes (including tariffs and subsidies), and investment spending ratios relative to GDP .

\subsection{Steady State}

On a steady state the ratio $\alpha$ will converge to a constant. In particular, from (45), on a steady state where $f_{t+1}^{r}=f_{t}^{r}$ we have a steady state feasibility condition

$$
\bar{f}^{r}=\frac{1+\gamma}{\gamma-\rho}\left(\alpha^{r}-\chi^{r}\right)
$$

Which defines steady state consumption, $\bar{\chi}^{r}$. Thus steady state investment to GDP ratios, tax rates, government spending and debt targets determine steady state consumption, $\bar{\chi}^{r}$. Clearly if the long run debt target is set to zero, then $\bar{f}=0$ so $\alpha=\chi^{r}$. This completes the description of the consumption and foreign asset dynamics.

On a steady-state the growth rate of each capital stock must be equal to $\gamma$, the long run growth rate. For each region $r \in R$ this gives,

$$
\frac{Q_{k}^{r}}{V_{k}^{r}}=\delta+\gamma, k \in K
$$

Likewise on a steady state the updating equation for human capital (40) becomes

$$
\frac{H^{r}}{L S^{r}}=b^{r} \zeta
$$

The equations replace the updating equations (39) and (40). In addition we need to determine the steady state path of the asset prices $\Pi_{k}^{r}$ and $\Pi_{k}^{r}$. From (14) we have $\Pi_{k}^{r}=u_{k} /\left(\rho+\delta_{k}\right)$. Using this (13) and (15) gives

$$
e_{k}^{r}=\frac{u_{k}}{\rho+\delta_{k}}, k \in K
$$

Thus on a steady state there is a linear relationship between investment price index and the rental rate. This represents six additional equations that must hold in a steady-state equilibrium relative to the static equilibrium on a point along the transition path. The 
additional endogenous variables are the endowments $V_{k}^{r}$ for $k \in K$ and $r \in R$.

The steady state asset prices and rental for skilled labor are determined in a similar manner. As described in the text the wage rates, $u_{u, t}^{r}, u_{u, t}^{r}$, and shadow price $\Pi_{t}^{r}$ must be growing at the growth rate of productivity, $1+\gamma$ on the balanced growth path. Let $\hat{\Pi}_{e, t}^{r} \equiv \Pi_{e, t}^{r} / A_{s, t}, u_{u, t}=\hat{u}_{u, t} / A_{u, t}$, and $\hat{u}_{s, t}=u_{s, t} / A_{s, t}$. On a steady-state we have $\hat{\Pi}_{e, t}=\hat{\Pi}_{e, t+1}, \hat{u}_{s, t}=\hat{u}_{s, t+1}, \hat{u}_{u, t}=\hat{u}_{u, t+1}$ and $J\left(H^{r}, L S^{r}\right)=0$. In the benchmark we choose units so that the ratio of efficiency units of unskilled to skilled labor is $A_{u} / A_{s} \equiv 1$.

Given these assumptions (7) becomes

$$
\hat{\Pi}_{e}^{r}=\Delta\left(\hat{u}_{s}-\hat{u}_{u}\right)
$$

where $\Delta \equiv(1+g) /((1+\rho)-(1-d)(1+g))$. This shows that the asset price of a unit of skilled labor is simply proportional to the skilled unskilled wage gap. Likewise on a steady state (35) becomes

$$
\hat{\Pi}_{e}^{r}=\zeta\left(\hat{u}_{u}+q_{e}\right)
$$

which shows that the asset price of a unit of skilled labor is simply equal to the opportunity and direct costs of schooling. Combining these expressions gives the steady state relationship between the skill premium and the price of education.

$$
\hat{u}_{s}-\hat{u}_{u}=\left(q_{e}+\hat{u}_{u}\right)(\zeta / \Delta) .
$$

This represents 2 additional equations that must hold in a steady-state and the two additional variables are $L S^{r}$ for $r \in R$.

In a static equilibrium at time $t$ the values of $\Pi_{k, t}^{r}$ and $\Pi_{k, t+1}^{r}$ are taken as given along with the endowment vectors $V_{k, t}^{r}$, consumption to GDP ratio $\chi_{t}^{r}$, and debt to GDP ratio $\bar{f}_{t}^{r}$. Formally we have:

Definition 2. A steady state equilibrium is a static equilibrium in which, for each region $r \in R$, aggregate investment and schooling demands are described by (15) and (48) and there also exists: a quantity of skilled labor, $L S^{r}$; a set of capital stocks, $V_{k, t}^{r}, k \in K$, and; a value of consumption spending $\chi^{r}=\bar{\chi}^{r}$; that satisfy: the market clearing equations in Definition 1; the steady state consumption condition, (46); the steady sate investment pricing conditions (16); and the skilled-labor premium condition (9); for given values of $\bar{f}^{r}$, and world prices, $q_{i}^{3}$. 


\section{Definitions - For Referee}

\begin{tabular}{|c|c|}
\hline Sets & \\
\hline Regions & $\bar{R} \in\{1,2,3\}$ \\
\hline Non ROW regions & $R \in\{1,2\}, R \subset \bar{R}$ \\
\hline Sectors $I$ & $I=\{1, \ldots, 11\}$ \\
\hline Traded Sectors, $I_{T}$ & $I_{T}=\{1, \ldots, 6\}, I_{T} \subset I$ \\
\hline Non Traded Sectors, $I_{N}$ & $I_{N}=\{7, \ldots, 11\}, I_{N} \subset I$ \\
\hline Spending types, $Z$ & $Z=\{1, \ldots, 5\}$ \\
\hline Factors, $\bar{K}$ & $\bar{K}=\{1, \ldots, 7\}$ \\
\hline Physical Capital Factors, $K$ & $K=\{1, \ldots, 3\}, K \subset \bar{K}$ \\
\hline Regions & \\
\hline 1 & $U S A$ \\
\hline 2 & China or India \\
\hline 3 & $R O W$ \\
\hline Spending Types & \\
\hline 1 & Machinery and Equipment Spending \\
\hline 2 & Structures Investment \\
\hline 3 & Residential Capital Investment \\
\hline 4 & Consumption \\
\hline 5 & Government \\
\hline Factors of Production & \\
\hline 1 & Machinery and Equipment \\
\hline 2 & Structures \\
\hline 3 & Residential Capital \\
\hline 4 & Skilled labor \\
\hline 5 & Unskilled labor \\
\hline 6 & Land \\
\hline 7 & Resources \\
\hline Sectors & \\
\hline 1 & Agriculture \\
\hline 2 & Minerals \\
\hline 3 & Low-tech \\
\hline 4 & Intermediate Manufacturing \\
\hline 5 & Durables \\
\hline 6 & Traded Services \\
\hline 7 & Construction \\
\hline 8 & Non-Traded Services \\
\hline 9 & Public \\
\hline 10 & Housing \\
\hline 11 & Education \\
\hline
\end{tabular}




\begin{tabular}{|l|l|}
\hline \multicolumn{2}{|l|}{ Non Price Variables } \\
\hline$g_{i}^{r}$ & Real gross output flow by sector $i, i \in I$ \\
$V_{W}$ & Endowment for ROW region \\
$V_{k}^{r}$ & Aggregate stock of reproducible input, $k, k \in K$ \\
$V_{k, i}^{r}$ & Stock of reproducible inputs in sector $i, k \in K, i \in I$ \\
$L S^{r}$ & Aggregate stock of skilled labor \\
$L U^{r}$ & Stock of unskilled labor \\
$M_{i}^{r}$ & Intermediate input aggregator for each sector $i$, \\
$a_{i, j}^{r}$ & Intermediate use coefficient for good $j$ by sector $I, i \in I, j \in I$ \\
$Y_{i, j}^{r}$ & Quantity of intermediate use for each good $j$ used as an input in sector $i$ \\
$x_{i}^{R, j}$ & Output of traded good in sector $i$ of region with destination $j \in\{1,2,3\}$ \\
$Q_{z}^{r}$ & Real quantity index for each spending type, $z \in Z$ \\
$G^{r}$ & Government spending for each region \\
$G D P^{r}$ & GDP at factor cost \\
$\omega^{r}$ & Ratio of government spending to GDP \\
$\chi^{r}$ & Ratio of consumption spending to GDP \\
$Q_{k}^{r}$ & Investment demand for asset type $k$ for each region $R, k \in\{M, S, D\}$ \\
$H^{r}$ & Stock students for each region \\
$E^{r}$ & Annual number of new graduates for each region \\
$A_{e}^{r}$ & Technical parameter for level of costs per student for each Region \\
$A_{k}^{r}$ & Technical parameter for level of effective factor supply \\
$f_{t}^{r}$ & Current level of net foreign assets to GDP ratio at time $t$ \\
$\bar{f}_{t}^{r}$ & Target level of net foreign assets to GDP ratio \\
$v_{i}^{r}$ & Value added in $R \in\{1,2\}$ \\
$\phi_{i}^{r}$ & Revenue in region $r \in \bar{R}$ \\
$J^{r}$ & On-the-job training cost function \\
$C_{k}^{r}$ & Capital installation costs function \\
$s u r p^{r}$ & Ratio of consumption spending to GDP \\
$l u m p^{r}$ & Lump sum tax to balance government budget. \\
\hline
\end{tabular}




\begin{tabular}{|c|c|}
\hline \multicolumn{2}{|c|}{ Prices } \\
\hline$\Pi_{L S}^{r}$ & Shadow price of a unit of skilled labor. \\
\hline$\Pi_{k}^{r}$ & Shadow prices of a unit of capital of asset type $k$. \\
\hline$\Pi_{e}^{r}$ & Shadow prices of a unit of skilled labor. \\
\hline$p_{k}^{r}$ & Producer prices of a unit of investment in each asset type $k \in\{M, S, D\}$ \\
\hline$u_{k}^{r}$ & After tax rental rates on asset type $k$ for each region \\
\hline$p_{i}^{\bar{R}, j}$ & $\begin{array}{l}\text { Producer prices in each region of sector } i \text { in region } \bar{R} \in\{1,2,3\} \text { sold in } j \in \\
\{1,2,3\} \text {. }\end{array}$ \\
\hline$q^{r}$ & Vector of consumer prices in each region \\
\hline$q_{i}^{r}$ & Consumer prices in each region for sector $i$. \\
\hline$e_{z}^{r}$ & Unit expenditure for each spending type. \\
\hline$p_{e}^{r}$ & Producer price of education inclusive of education subsidies \\
\hline$q_{e}^{r}$ & Consumer price of education inclusive of education subsidies \\
\hline$d_{z, i}^{r}$ & Demand for sector $i$ from spending type $z$. \\
\hline$u_{s}^{r}$ & After tax skilled wages for each region $R$. \\
\hline$u_{u}^{r}$ & After tax unskilled wages for each region $R$. \\
\hline$w_{k}$ & Factor prices. \\
\hline$\hat{w}_{k}$ & Factor prices per efficiency unit. \\
\hline \multicolumn{2}{|c|}{ Parameters } \\
\hline$\delta_{k}$ & Depreciation rates on asset type $k$. \\
\hline$\Gamma_{k}^{r}$ & Factor tax \\
\hline$\tau^{j \bar{R}}$ & Tariff rate rates by region $j$ on each region $\bar{R}$ 's exports. \\
\hline$\sigma$ & Elasticity of substitution parameter in upper nest of cost function \\
\hline$\nu$ & Elasticity of substitution parameter in lower nest of cost function \\
\hline$\beta_{k}^{r}$ & Parameter of the adjustment cost function. \\
\hline$\beta_{e}^{r}$ & Parameter for the adjustment cost function for human capital \\
\hline$\gamma$ & Steady state growth rate of the economy. \\
\hline$\alpha$ & Parameter for the growth rate of consumption per worker. \\
\hline$\zeta$ & Number of years in which new graduates have attended school \\
\hline$n^{r}$ & labor Force growth rate. \\
\hline$\lambda^{r}$ & Debt target parameter in the inter-temporal consumption function \\
\hline
\end{tabular}




\section{Tables}

Table 1: Tariff Rates

China's tariff China's tariff India's tariff India's tariff

on USA on ROW on USA on ROW

$\begin{array}{lllll}\text { Agriculture } & 0.55 & 0.28 & 0.24 & 0.47 \\ \text { Minerals } & 0.06 & 0.02 & 0.20 & 0.16 \\ \text { Low-Tech Manufacture } & 0.10 & 0.13 & 0.20 & 0.25 \\ \text { Intermediate Manufacture } & 0.10 & 0.12 & 0.31 & 0.30 \\ \text { Durables } & 0.11 & 0.15 & 0.21 & 0.27 \\ \text { Traded Services } & 0.19 & 0.19 & 0.13 & 0.13\end{array}$


Table 2: Trade Shares

China China India India

Import Export Import Export

Shares Shares Shares Shares

$\begin{array}{lllll}\text { Agriculture } & 0.05 & 0.04 & 0.08 & 0.11 \\ \text { Minerals } & 0.06 & 0.02 & 0.20 & 0.02 \\ \text { Low-Tech Manufacture } & 0.30 & 0.46 & 0.04 & 0.25 \\ \text { Intermediate Manufacture } & 0.21 & 0.13 & 0.23 & 0.20 \\ \text { Durables } & 0.22 & 0.28 & 0.26 & 0.21 \\ \text { Traded Services } & 0.15 & 0.06 & 0.19 & 0.20\end{array}$


Table 3: Key Parameter Values (all regions)

Base Values

CET Elasticities of Supply

Agriculture $\quad 3.90$

Minerals 2.90

Low-Tech Manufacture $\quad 2.90$

Intermediate Manufacture $\quad 2.90$

Durables 2.90

Traded Services $\quad 0.70$

CES Expenditure Function Elasticities of Demand

Consumption $\quad-0.80$

Government $\quad-0.80$

Machinery and Equipment $\quad-0.80$

Structures $\quad-0.80$

Residential Housing $\quad-0.80$

CES Unit Cost Functions

Upper Nest Substitution Elasticity, $\sigma \quad 1.67$

Lower Nest Substitution Elasticity, $\nu \quad 0.67$

$\begin{array}{ll}\text { Investment Adjustment Cost Parameter, } \beta_{k} & \\ \text { Machinery and Equipment } & 10.0\end{array}$

$\begin{array}{lr}\text { Structures } & 90.0\end{array}$

Residential Housing $\quad 90.0$

Training Cost Function Parameter, $\beta_{e} \quad 6.0$ 
Table 4. Steady State Calibration

\section{China India}

Skilled Labor (Faction of Labor Force) $\quad L S / P \quad 0.02 \quad 0.02$

Students as a fraction of Labor Force ${ }^{1} \quad H / L S \quad 0.35 \quad 0.35$

Tertiary Edu. Exp (\% of GDP) ${ }^{2} \quad p_{e} y_{e} \quad 0.80 \quad 0.99$

Years of tertiary schooling $\quad z \quad 4.00 \quad 4.00$

$\begin{array}{llll}\text { Education subsidy } & s & 0.57 & 0.77\end{array}$

Implied Skill Premium $\quad w_{L S} / w_{L U} \quad 2.55 \quad 2.32$

1. Source of Skilled labor stocks: China and India Barro and Lee (2001).

2. Sources of education expenditure data: China OECD (2002), Online Education database, Table B2.1a, B2.1b. available at http://www.oecd.org/education/database; India, UNESCO Institute for Statistics, http://www.uis.unesco.org/. 
Table 5: Trade Liberalization In China and India Summary (\% change)

\begin{tabular}{lcccc}
\hline & & & & \\
& $\begin{array}{c}\text { China } \\
\text { Impact }\end{array}$ & China & India & India \\
& & & & \\
& & & & \\
& 1.6 & 6.7 & 3.0 & 19.0 \\
Real Factor Income & SS \\
Skilled Wages & 4.1 & 3.7 & 12.6 & 11.5 \\
Unskilled Wages & 2.4 & 4.7 & 4.2 & 12.3 \\
Skill Premium & 1.7 & -1.0 & 8.1 & -0.7 \\
Skilled Labour, LS & 0.0 & 8.0 & 0.0 & 19.9 \\
Net Skilled Labor Supply & -0.4 & 8.0 & -3.9 & 19.9 \\
Unskilled Labor, LU & 0.0 & -0.2 & -0.1 & -0.6 \\
Students & 3.4 & 8.0 & 9.6 & 20.0 \\
Machines per unskilled worker & 0.0 & 13.0 & 0.1 & 35.7 \\
Structures per unskilled worker & 0.0 & 10.2 & 0.1 & 27.9 \\
Residential per unskilled worker & 0.0 & -0.1 & 0.1 & 6.8 \\
& & & & \\
\hline
\end{tabular}


Table 6: Decomposition of Steady State Factor Supply Changes in China, \%

Total Change Output Effect Factor Intensity Effect

$\begin{array}{lccc}\text { Machinery and Equipment } & 12.8 & 8.5 & 4.3 \\ \text { Structures } & 10.1 & 7.1 & 3.0 \\ \text { Residential Capital } & -0.2 & -1.3 & 1.1 \\ \text { Skilled Labor } & 8.0 & 6.9 & 1.1 \\ \text { Unskilled Labor } & -0.2 & 4.6 & -4.8\end{array}$


Table 7: Decomposition of Steady State Factor Supply Changes in India \%

Total Change Output Effect Factor Intensity Effect

$\begin{array}{lccc}\text { Machinery and Equipment } & 35.0 & 25.9 & 9.1 \\ \text { Structures } & 27.4 & 21.9 & 5.6 \\ \text { Residential Capital } & 6.4 & 4.8 & 1.6 \\ \text { Skilled Labor } & 20.2 & 19.0 & 1.2 \\ \text { Unskilled Labor } & -0.6 & 11.9 & -12.5\end{array}$


Table 8: Partial Trade Liberalization - Excluding Agriculture

\begin{tabular}{lcccc}
\hline & & & & \\
& $\begin{array}{c}\text { China } \\
\text { Impact }\end{array}$ & China & Sndia & India \\
& & & & \\
& & & & \\
& 1.4 & 5.0 & 2.7 & 13.3 \\
Real Factor Income & SS \\
Skilled Wages & 2.5 & 2.8 & 6.2 & 8.5 \\
Unskilled Wages & 2.0 & 3.7 & 3.6 & 9.3 \\
Skill Premium & 0.5 & -0.8 & 2.6 & -0.7 \\
Skilled Labor, LS & 0.0 & 5.1 & 0.0 & 12.3 \\
Net Skilled Labor Supply & -0.1 & 5.1 & -1.4 & 12.3 \\
Unskilled Labor, LU & 0.0 & -0.2 & 0.0 & -0.4 \\
Students & 2.0 & 5.2 & 5.7 & 12.4 \\
Machines per unskilled worker & 0.0 & 8.8 & 0.1 & 23.9 \\
Structures per unskilled worker & 0.0 & 7.2 & 0.1 & 17.9 \\
Residential per unskilled worker & 0.0 & 0.4 & 0.1 & 9.4 \\
& & & & \\
\hline
\end{tabular}


Table 9: Sensitivity to Capital-Skill Complementarity

\begin{tabular}{lccc}
\hline Case & $\begin{array}{c}\text { Direct Elasticity } \\
\text { of Substitution } \\
\text { in the Upper } \\
\text { Nest, } 1-\sigma\end{array}$ & $\begin{array}{c}\text { Direct Elasticity } \\
\text { of Substitution } \\
\text { in the Lower } \\
\text { Nest, } 1-\nu\end{array}$ & $\nu-\sigma$ \\
& & & \\
\hline High & $12 / 3$ & $1 / 3$ & $11 / 3$ \\
Medium (Base Case) & $12 / 3$ & $2 / 3$ & 1 \\
Zero (CES) & $12 / 3$ & $12 / 3$ & 0 \\
Substitutes & $12 / 3$ & 3 & $-11 / 3$ \\
& & & \\
\hline
\end{tabular}


Table A1: Results - Trade Liberalization In China (\% change)

\begin{tabular}{|c|c|c|c|c|}
\hline & Impact & Year 5 & Year 10 & $S S$ \\
\hline Real Factor Income, $Y$ & 1.6 & 3.0 & 4.0 & 6.7 \\
\hline Real GDP & -1.6 & -0.3 & 0.7 & 3.3 \\
\hline Real Govt. and Private Consumption & -2.9 & -2.0 & -1.1 & 1.0 \\
\hline Investment in Machinery and Equipment & 6.6 & 4.6 & 3.7 & 3.6 \\
\hline Investment in Structures & 3.1 & 2.6 & 2.5 & 3.1 \\
\hline Investment in Housing & -5.7 & -6.0 & -6.1 & -6.5 \\
\hline Real return to Machine and Equipment & 5.3 & 1.0 & -0.8 & -1.9 \\
\hline Real return to Structures & 3.4 & 3.9 & 3.3 & 0.0 \\
\hline Real return to Housing & -5.7 & -3.3 & -1.4 & 0.1 \\
\hline Machines per unskilled worker & 0.0 & 5.0 & 7.8 & 13.0 \\
\hline Structures per unskilled worker & 0.0 & 1.8 & 3.7 & 10.2 \\
\hline Residential per unskilled worker & 0.0 & -1.2 & -1.9 & -0.1 \\
\hline Real Skilled wages & 4.1 & 5.3 & 5.6 & 3.7 \\
\hline Real Unksilled wages & 2.4 & 3.0 & 3.4 & 4.7 \\
\hline Land rents & -5.2 & -4.1 & -3.2 & -1.4 \\
\hline Resource rent & -1.1 & -0.3 & 0.2 & 1.4 \\
\hline Skill Premium & 1.7 & 2.3 & 2.1 & -1.0 \\
\hline Education Output relative to GDP & 1.7 & 1.1 & 0.9 & 1.1 \\
\hline Skilled Labor, LS & 0.0 & 1.1 & 2.4 & 8.0 \\
\hline Unskilled Labor, LU & 0.0 & -0.1 & -0.1 & -0.2 \\
\hline$L S / L U$ & 0.0 & 1.2 & 2.5 & 8.1 \\
\hline Students & 3.4 & 4.2 & 4.9 & 8.0 \\
\hline Net Skilled Labor Supply & -0.4 & 0.8 & 2.1 & 8.0 \\
\hline Relative Price of Education $\left(P_{e} / w_{L U}\right)$ & -0.5 & -1.1 & -1.6 & -3.2 \\
\hline Exchange Rate (Traded $v$ Non Traded) & -0.7 & -1.1 & -1.2 & -1.1 \\
\hline Terms of Trade & -6.7 & -6.8 & -6.9 & -7.2 \\
\hline Openness & 32.6 & 31.6 & 30.7 & 28.5 \\
\hline Trade Volume China - USA & 26.3 & 28.5 & 29.3 & 31.1 \\
\hline Trade Volume China - ROW & 22.7 & 24.4 & 25.0 & 26.6 \\
\hline Trade Surplus/GDP (Level) & -0.3 & 0.1 & 0.1 & 0.0 \\
\hline \multicolumn{5}{|l|}{ Sector Outputs } \\
\hline Agriculture & -9.6 & -8.9 & -8.2 & -6.6 \\
\hline Minerals & 1.7 & 3.4 & 4.8 & 9.3 \\
\hline Low-Tech & 19.3 & 21.7 & 22.5 & 24.1 \\
\hline Intermediate Manufacture & 0.1 & 2.0 & 3.3 & 7.1 \\
\hline Durables & 2.0 & 4.1 & 5.5 & 9.3 \\
\hline Traded Services & -2.5 & -0.6 & 0.9 & 4.8 \\
\hline Construction & 1.5 & 2.8 & 4.0 & 7.4 \\
\hline Non Traded Services & 0.7 & 2.2 & 3.3 & 6.4 \\
\hline Public & 0.0 & 1.3 & 2.4 & 5.3 \\
\hline Housing & -3.4 & -3.3 & -2.9 & -1.3 \\
\hline Education & 3.4 & 4.2 & 4.9 & 7.9 \\
\hline
\end{tabular}


Table A2: Results - Trade Liberalization In India (\% change)

\begin{tabular}{|c|c|c|c|c|}
\hline & Impact & Year 5 & Year 10 & $S S$ \\
\hline Real Factor Income, $Y$ & 3.0 & 7.5 & 10.8 & 19.0 \\
\hline Real GDP & -2.2 & 2.1 & 5.2 & 13.0 \\
\hline Real Govt. and Private Consumption & -5.8 & -3.2 & -0.3 & 6.7 \\
\hline Investment in Machinery and Equipment & 14.0 & 10.6 & 8.5 & 7.4 \\
\hline Investment in Structures & 8.4 & 6.8 & 6.2 & 7.1 \\
\hline Investment in Housing & -6.4 & -7.9 & -8.8 & -10.6 \\
\hline Real return to Machine and Equipment & 8.6 & 0.4 & -3.5 & -5.6 \\
\hline Real return to Structures & 4.8 & 7.7 & 7.3 & 0.0 \\
\hline Real return to Housing & -8.7 & -5.0 & -1.6 & 0.1 \\
\hline Machines per unskilled worker & 0.1 & 12.3 & 20.5 & 35.7 \\
\hline Structures per unskilled worker & 0.1 & 4.5 & 9.4 & 27.9 \\
\hline Residential per unskilled worker & 0.1 & -1.2 & -1.3 & 6.8 \\
\hline Real Skilled wages & 12.6 & 14.9 & 15.3 & 11.5 \\
\hline Real Unksilled wages & 4.2 & 6.5 & 8.1 & 12.3 \\
\hline Land rents & -8.8 & -7.2 & -5.4 & -1.5 \\
\hline Resource rent & -6.4 & -1.7 & 2.4 & 17.5 \\
\hline Skill Premium & 8.1 & 7.8 & 6.6 & -0.7 \\
\hline Education Output relative to GDP & 6.4 & 3.5 & 2.0 & 0.8 \\
\hline Skilled Labor, LS & 0.0 & 3.1 & 6.4 & 19.9 \\
\hline Unskilled Labor, Lu & -0.1 & -0.2 & -0.2 & -0.6 \\
\hline$L S / L U$ & 0.1 & 3.3 & 6.7 & 20.7 \\
\hline Students & 9.6 & 11.3 & 13.0 & 19.9 \\
\hline Net Skilled Labor Supply & -3.9 & 0.4 & 4.7 & 19.9 \\
\hline Relative Price of Education $\left(P_{e} / w_{L U}\right)$ & 0.6 & 0.0 & -0.7 & -3.3 \\
\hline Exchange Rate (Traded v Non Traded) & -3.8 & -4.3 & -4.4 & -3.4 \\
\hline Terms of Trade & -8.8 & -9.2 & -9.6 & -10.6 \\
\hline Openness & 59.8 & 58.2 & 56.1 & 50.6 \\
\hline Trade Volume India - USA & 50.6 & 61.3 & 65.8 & 73.2 \\
\hline Trade Volume India - ROW & 39.9 & 46.1 & 49.5 & 57.0 \\
\hline Trade Surplus/GDP (Level) & -1.2 & 0.2 & 0.3 & 0.0 \\
\hline \multicolumn{5}{|l|}{ Sector Outputs } \\
\hline Agriculture & -14.6 & -13.5 & -12.2 & -9.3 \\
\hline Minerals & -9.8 & 3.1 & 15.8 & 74.0 \\
\hline Low-Tech & 28.8 & 30.5 & 30.9 & 32.6 \\
\hline Intermediate Manufacture & -1.5 & 8.4 & 14.6 & 29.7 \\
\hline Durables & 32.0 & 50.4 & 59.4 & 75.4 \\
\hline Traded Services & 4.3 & 12.9 & 19.0 & 32.7 \\
\hline Construction & 4.3 & 8.5 & 11.9 & 21.9 \\
\hline Non Traded Services & 0.3 & 4.9 & 8.6 & 17.9 \\
\hline Public & -3.6 & -1.1 & 1.5 & 8.5 \\
\hline Housing & -3.0 & -2.1 & -0.6 & 4.6 \\
\hline Education & 9.6 & 11.3 & 13.0 & 20.0 \\
\hline
\end{tabular}

